\title{
Competition in the Service Sector and the Performances of Manufacturing Firms: Does Liberalization Matter?
}

\author{
Emanuele Forlani
}

CESIFO WORKING PAPER No. 2942

CATEGORY 11: INDUSTRIAL ORGANISATION

FEBRUARY 2010

\footnotetext{
An electronic version of the paper may be downloaded

- from the SSRN website: www.SSRN.com

- from the RePEc website:

- from the CESifo website: 


\title{
Competition in the Service Sector and the Performances of Manufacturing Firms: Does Liberalization Matter?
}

\begin{abstract}
Services form an increasing proportion of the inputs used in manufacturing. We explore empirically whether competition in the service sector affects downstream manufacturing firms' efficiency, via the inputs used. Using French micro-data for services, we calculate proxies for competition in services, and then use Input-Output matrices to link services to manufacturing sectors. we find that there is a positive and significant relation between the extent of competition and firms' productivity.
\end{abstract}

JEL-Code: F10, F12, F13, L80.

Keywords: services liberalization, productivity, input-output tables, competition.

\author{
Emanuele Forlani \\ Catholic University of Louvain \\ Center for Operation Researchs and Econometrics \\ Voie du Roman Pays, 34 \\ B - 1348 Louvain-la-Neuve \\ Belgium \\ emanuele.forlani@uclouvain.be
}

I am grateful to H. Vandenbussche, G.I.P. Ottaviano, H. Raff, G. Mion, and D. Castellani for useful comments on this research. In addition I am grateful to EARIE and CESifo for financial support. 


\section{Introduction}

In recent years the production and consumption of services has been very important in developed economies. The so-called tertiary sector accounts for a large part of their GDP and it employees a large percentage of the labor force; the share of GDP in Europe, due to services, rose $52.2 \%$ to $70 \%$ between 1970 and 2000. This growth does not depend only on changes in consumers' preferences toward service goods; manufacturing firms use an increasing share of services as inputs to their production process. The traditional sectors, such as machinery, equipment or textiles, use services to organize production, sell their output and manage their financial activities: transport, banking, retailing, energy and telecommunications provide inputs which are fundamental for firms' life cycles. Looking at input-output tables of OECD countries it is possible to observe the rising importance of service providers as suppliers for manufacturing; for example UK firms increased their service input from $25 \%$ in 1984 to $44 \%$ of $1995^{1}$. In France, the share of services increased by $17 \%$ in the period $1995-2000^{2}$, at the end of which period services accounted for $28 \%$ of all inputs; finally in Italy services comprised $11 \%$ of manufacturing firms' costs in ${ }^{3}$. Nonetheless, despite these empirical observations, much of the economic literature does not explicitly consider services as an input to production process.

Since an increasing proportion of the inputs to manufacturing sectors are services, I will analyze in this paper, how competition in services plays a relevant role for downstream (manufacturing) firms. Then paper's core aim is to explore whether competition in services affects firms' performance, such as their productivity. Why should competition in services should affect manufacturing firms' performance via inputs? There are three main reasons for this. First, more competition in services may be a strong incentive to upgrade the quality of the services provided. Second, resources no longer used to pay for inefficient services, could be used by manufacturing firms for other investments, such as R\&D activities. Third, there may be positive spillover effects, in terms of productivity, from service sectors to manufacturing. As the WTO has stated "it is impossible for any country to prosper today under the burden of an inefficient and expensive services infrastructure. Producers and exporters of textiles, tomatoes or any other product will not be competitive without access to efficient banking, insurance, accountancy, telecoms and transport systems.... The benefits of services liberalization extend far beyond the service industries themselves; they are felt through their effects on all other economic activities[...] 4 "

This paper's fundamental contributions are two. First, competition in services is measured with different types of indices, using firm-level data, instead of using the indices provided by institutions (Arnold et al., 2006). Second the contribution to the literature on liberalization and competition in services is focused at the intersectoral linkage between services and with manufacturing (using input-output tables). The paper also adds some insights into the process of liberalization and deregulation of services in the EU which has taken place in the last ten years (especially for networks). The basic motivation underlying this analysis, is that services and manufacturing operate in two different competitive environments; in this framework a relevant issue arises when the less competitive sector (services) sells inputs to the more competitive one (manufacturing). Manufactured goods are usually involved in very competitive markets compared to services, while many service firms operate in a monopolistic (energy) or very protected (financial or business activities) market. Unlike manufacturing, services do not suffer from international competition, so there is less competitive pressure in the in tertiary sector. When manufacturing employs services as inputs in the production process the combination of anticompetitive domestic

\footnotetext{
${ }^{1}$ Riccardo Faini, Jonathan Haskel, Giorgio Barba Navaretti ,Carlo Scarpa, and Christian Wey "Contrasting Europe's decline: do product market reforms help?" Fondazione de Benedetti 2004

${ }^{2}$ Eurostat: Input-Output Tables 2000

3"Il Sole 24 Ore" 19/06/2005

${ }^{4}$ WTO-GATS FactBook (2005).
} 
regulation and protection against foreign competitors could strengthen the monopoly power of service providers and weaken the competitive position of those domestic firms that rely more intensively on service inputs. Hence, while manufacturing has been increasingly exposed to the forces of competition due to trade liberalization, services are relatively protected.

From a practical point of view the analysis is focused on France, instead of a developing country (Arnold et al., 2006; Fernandes and Paunov, 2008). Input-output matrices are used to evaluate the relative importance of services for each manufacturing sector. The data used are at firm level both for services and for manufacturing: while for services particular attention is devoted to network industries (energy distribution, transport and telecommunication), instead for manufacturing production function is estimated in order to obtain firms' total factor productivity (TFP).

The empirical estimations show that the market power of services affects downstream firms' productivity. It is find that there is a statistically significant relation between firms' productivity and competition in the service sector: as competition increases, so does the average productivity of manufacturing. This relationship is stronger when only network industries are considered. A second class of estimations then shows that the effect is not linear: up to a certain threshold, market power has a positive effect on firms' productivity, perhaps due to the exploitation of economies of scale. Thus perfect competition in services should not be an objective for policy makers, especially in network sectors. Finally, it seems that large manufacturing firms benefit more than small firms from service liberalization.

This paper is organized as follows. Section 2 discusses the relevant literature, while Section 3 briefly presents France's network services market. The data and empirical procedure are discussed in Section 4, while Section 5 presents the results. Finally conclusions are given in Section 6.

\section{Related Literature}

Interest in the issue of service-sector liberalization and the input-output linkages between the service and manufacturing sectors is quite recent. One of the most important papers on service liberalization and manufacturing productivity is that by Arnold, Javorcik and Mattoo (2006). They show that service liberalization has had a positive impact on the average productivity of downstream manufacturing firms in the Czech Republic. They empirically demonstrate that liberalization in services improved the efficiency of manufacturing firms. Using input-output matrices for the Czech Republic they link the liberalization of services with firms' productivity; using five different indices which proxy competition for each service sector, they are able to evaluate the impact of liberalization on productivity and productivity growth. They also emphasize that most of the barriers to foreign investment are in the service sector rather than in manufacturing. They conclude that it is important to support market liberalization in services, in particular by admitting new foreign investors. Their approach is based on the intuition that services are used as inputs for production: better inputs (lower cost and higher quality) improve performance in downstream sectors. In a similar paper, Fernandes and Paunov (2008) show, by analyzing information about the use of services at plant level, that inward FDI service sectors have a positive effect on manufacturing firms' productivity in Chile

An interesting contribution to this line of thinking is Amiti and Konings' (2007) paper. They show that the productivity of Indonesian manufacturing firms increased when taxes on input imports were reduced: where imported goods are used as inputs, a decrease of $10 \%$ in the import tariff increases the firms' productivity by $12 \%$, on average, via learning and the variety and quality effects. Amiti and Konings used a dataset of Indonesian manufacturing firms with information about the composition of their inputs, in terms of quantity, type and origins for 
each firm. As trade liberalization was introduced they could demonstrate an increase in the quantity (variety effect) and quality (quality effect) of the imported goods used as inputs in the production process. High quality inputs means quality and efficiency upgrading, while less costly inputs means that the final product is cheaper. Unlike Arnold et al. (2006), Amiti and Konings considered not only services as input but all kind of intermediates in the production process. Kasahara and Lapham (2006) adopted a similar approach. They created a dynamic model in which firms simultaneously choose to export goods and import intermediates. The estimation of structural model shows that restricting the imports for input reduces the number of Chilean exporting firms; moving from a situation of free trade situation in intermediates to one of no trade, reduces the percentage of exporter from $17.2 \%$ to $12.4 \%$. They argue that cheaper and more varied inputs increases the productivity of firms and consequently their capacity to compete on international markets ${ }^{5}$.

It is more difficult to deal with service liberalization and input-output linkages from a theoretical point of view. Theoretical papers tend to be more oriented towards manufacturing firms' cost reduction than their efficiency gains. For example, Fugazza and Robert-Nicoud (2007) demonstrated, in a monopolistic competitive framework à la Dixit-Stigliz-Krugman, that trade liberalization in intermediate inputs decreases the productivity cut-off for the exporting activity, due to a cost reduction. More interesting pointers, for this paper's purposes, come from Grossman and Helpman (1991). They showed that a monopolistic competitive sector, which produces horizontally differentiated intermediate inputs for a single consumption-good producer, increases the downstream TFP provided the variety of intermediate inputs also expands. Finally, Gabsewicz and Zanaj (2007) developed a partial equilibrium model from a different perspective: they found that competition in upstream markets (à la Cournot) affects the profit of downstream firms, and the direction of the effect depends on the downstream cost structure. In addition they showed that there is an optimal ratio between the mass of downstream and upstream firms, for which the profits of the downstream market increase as competition in the upstream market increases

\section{Networks in France: an example of service sector}

In this section are briefly described European Union (EU) and France service sectors, in particular focusing on the analysis of networks industries. The EU is characterized by free trade in commodities but not free trade in services. The low competitive pressure in services depends on many factors, of which four are the most important. First, some services, such as transport or telecommunications (networks) are natural monopolies with high entry costs (for network duplication or network accessibility). Second, services, in Europe in particular, have traditionally been largely state owned or highly regulated in order to maintain low prices, and to overcome market failures such as asymmetric information. Third, services such as transport or telecommunication have been state owned for reasons of national strategic interest. Fourth, providers must be located near service users (firms or consumers) because of their intrinsic nature and, unlike manufactured goods, they cannot easily be imported ${ }^{6}$.

\footnotetext{
${ }^{5}$ Another empirical paper which deal with market liberalization is due by Pavcink (2002): she calculates that liberalized sectors, in Chile, gain an increase in productivity of $10 \%$ higher than no imports-competing firms. The Czech manufacturing firms may be involved in the same process independently from service liberalization.

${ }^{6}$ Sector as retailing it is not so highly regulated, compared to the other services. It is important to notice that the characteristics across services are highly heterogenous.
} 
The EU tried to deal with competition in the service sector in the so-called "Bolkenstein reform" (Bolkestein Directive, 2006; Pisani-Ferry, 2006). The reform was introduced in an effort to encourage competition between European service providers so as to foster efficiency and quality in services; the main declared objective was to incentives free trade in services across European countries, with the benefits split between consumers and firms. The relevance of services for manufacturing firms is stressed by Gordon (2004) and Pisani-Ferry(2006), who claim that differentials in productivity growth between Europe and the USA depend on different regulation of the services market. They assert that the poor European performance is due to inefficiencies in services. While in EU service providers are very protected and the EU market is fragmented, in the USA services are completely free to move from one state to another and to compete in a larger market. This paper addresses some of these issues. It is important to understand whether the liberalization and deregulation process due to European Union directives is relevant, and to what extent it should be encouraged. In particular the case of France is considered in this analysis

In 2000 France service's sector ${ }^{7}$ accounted for $70 \%$ of the country's GDP and $71 \%$ of its labor force (OECD Survey 2000). On average, services accounted for $28 \%$ of the total inputs to manufacturing sectors; this is relatively low compared to the UK or Germany, where services accounted for $44 \%$ and $39 \%$ respectively (Barba-Navaretti et al., 2004). However the French figure increased by $17 \%$ in the five years from 1995 to 2000.

Traditionally, a large proportion of service firms in France are state-owned or under public control, and this is particularly true for network industries, such as telecommunications, energy (production and distribution) and transport. Public utilities are vertical integrated, so even if the network's owner is competes in the market itself (e.g. Electricite de France, EDF) it has to provide network access to all potential competitors for a reasonable price. The role of the state is strong, especially in strategic sectors such as energy and telecommunications (TLC); the state often influences the investment decisions of foreign firms. It is worth mentioning the recent case of the Enel-Suez merger. In 2006 the French government blocked the hostile bid of the Italian group Enel for the privately owned firm, Suez (a vertically integrated energy firm). Instead they merged it with the state-owned Gas de France ${ }^{8}$, in order to maintain control of energy production and distribution in France.

A process of service sector deregulation began in 1998, and this has already yielded some results. Following EU directives, France implemented reforms in the energy market with two new laws, one in 2000 opening 30\% of the market to competition and another in 2003 with $35 \%$. It created RTE, a network management company independent of EDF; RTE is required to provide producers with free and equal access to its transmission network. Since 2000 business customers have had a free choice of suppliers, and this has been true for private customers since 2000: by April 2000, some 52 business customers (9\%) had cancelled their contract with EDF ${ }^{9}$. This situation put pressure on prices, resulting, in substantial price cuts for business customers. The first French deregulation reforms have begun to produce positive externalities, in terms of lower prices, more diversified supply, and improved quality, and it has had an impact on economic activity. Table 3.1 shows the potential benefits of deregulation for all sectors (services and manufacturing). The net potential maximum gain for the next ten years is estimated at an annual growth of $1.41 \%$ in multi-factor productivity (MFP). From Table 3.1 it is clear that there is a potential improvement in efficiency, with a reduction in state ownership of the economy. However it is not clear to what extent increasing competition in services brings gains for the efficiency of manufacturing firms.

\footnotetext{
${ }^{7}$ There is a list of the services considered in the analysis in Appendix B.

${ }^{8}$ The Economist 26/08/2006

${ }^{9}$ OECD France Survey 2001
} 
Table 3.1: Effect of easing regulation on MFP ${ }^{\ddagger}$.

\begin{tabular}{|c|c|c|}
\hline & $\begin{array}{c}\text { MFP growth over ten years } \\
\text { \% increase in the annual rate }\end{array}$ & $\begin{array}{c}\text { Inward FDI } \\
\text { increase in level }\end{array}$ \\
\hline \hline Economy wide regulation & 0.19 & 0.57 \\
\hline Industry specific regulation & 0.43 & - \\
\hline State ownership & 0.79 & - \\
\hline FDI restrictions & - & 0.10 \\
\hline
\end{tabular}

$\ddagger$ Source: OECD France Survey 2005

Comparing sector data yields more interesting insights. Figure 1 (in Appendix B) shows that productivity growth in France was driven in large part by growth in the manufacturing sector $^{10}$, rather than services. Using service data at the firm level illustrates the heterogeneity of characteristics in the French service sector. In particular, the development of the electricity, TLC and other business activity (OBA) sectors are analyzed. Then indices are calculated at sector level (2-digit NACE) to proxy the level of competition and efficiency. Figure (b) shows that the labor productivity (value added per worker) in the electricity sector varied impressively across time, possibly because of reorganization in the sector after the liberalization in 1998 and 2000. Productivity in both TLC and OBA increased, but with a more regular path (at least for OBA). However both TLC and electricity show a negative trend around the year 2000. The growth or decline in productivity may depend on variations in the level of employment or value added (due to reforms in the service sector and the labor market), rather than on gains in technical or allocative efficiency. The downturn in performance is probably due to a sharp decrease in the firms' value added as a consequence of the reforms in public networks brought about by the European Union's directives. An additional explanation may lie in the slow implementation of regulatory reform: the OECD claims that the liberalization of network industries in France lagged behind that of other large continental countries.

Figure (c) shows the average price cost margin (PCM) of services (Tybout, 2003): this is a proxy for the average mark-ups in each sector. The average PCM increased for TLC and decreased for electricity, reaching a similar level in 2004: as for labor productivity, there was a sharp decrease in PCM around the year 2000, the year of the liberalization. Conversely, there was a steady increase in PCM in the telecommunications industry: this might be explained by the larger presence of private firms, without the serious market deregulation that fosters competition, so that private firms are imposing monopoly prices. As discussed above, if liberalization occurs without deregulation, private firms may partially substitute for the incumbent public firms. Barba-Navaretti et al. (2004) suggest that liberalization without deregulation may be ineffective, because it can create a dominant position for the new incumbents, who have profits rather than social welfare as their objective.

In the rest of this paper it will be considered liberalization and deregulation as two different and complementary strategies to encourage competition in services; the former means the potential entry of private actors while the latter means the relaxation of rules so as to facilitate entry to and exit from the market. For example, foreign direct investment (FDI) may encourage competition in services with the presence of new firms, but this is not inevitable. If the deregulation rules are not effective and precise, foreign competitors may enter directly as oligopolies, substituting for local firms, or creating a cartel with the national incumbent (Vandenbussche and Veurglers 1999). In this case liberalization, like encouraging FDI in services, does not have a clear positive effect on the efficiency of manufacturing firms unless the rule system for deregulation is effective.

\footnotetext{
${ }^{10}$ Source: EU-Klems
} 
Another interesting measure is the Herfindahl index (HHI) which is a good proxy for market concentration. Figure (d) shows that concentration decreased sharply in the TLC industry after 1998 when France Telecom lost its monopoly. Over the same period it increased in the electricity sector, rising to the same level (42\%) as in TLC in $2004^{11}$. Finally in Appendix B are reported some descriptive statistics for the service sector in Tables B1, B2, B3.

\section{Data Analysis}

In this section we test the hypothesis of service competition's impact on manufacturing firms' efficiency. Three important aspects characterize the empirical analysis, with respect to previous literature. First, the data comes from a developed country (France), instead of an economy in transition (the Czech Republic) or a middle income country ${ }^{12}$ (Chile). The degree of development is relevant, because there may be a "cointegration" problem between service liberalization and productivity (as in the Czech Republic). In a transition economy, the passage from socialism to a market economy changes the country's economic structure, given that the best firms remain in the market and the resources are reallocated towards the most productive firms. At the same time services are forced to be strongly liberalized and opened to foreign investments. Therefore we can observe simultaneously an increase in the average manufacturing productivity and rising competition in services: in this framework it is possible to overestimate the importance of services. A second interesting issue is to verify the relevance and importance of the service sector in a developed economy, because firms employ services as inputs more intensively in production process. A final point is that the indices used to proxy competition in the service sector can be calculated using firm-level data instead of composite indices ${ }^{13}$.

This section describes the data and how the variables are constructed. Data on both the manufacturing and the service sector were collected at the firm level. It covers the 31 industries ${ }^{14}$ listed in Appendix B. The data source is the Amadeus database published by Bureau van Dijk, which contains the annual balance sheet for a large number of French firms (Pisani-Ferry, 2006). Data were collected according to the 2-digit NACE code and the observations are harmonized with the ISIC Rev.3 classification to create the input-output matrices

\subsection{Service Industries}

Because of limitations on data availability, the analysis only covered medium and large service providers (i.e. firms with operating revenues of at least 1.5 million euros in 2004). This could be a problem when constructing sector indicators, in particular for the retail sector which is composed of many small businesses. However given the broad definition of each service sector, and the purposes of the paper, it seems likely that a good proxy for the degree of competition can be obtained even from a partial dataset. In addition the empirical analysis is focused on network industries for which the dataset is more representative. By using firms' balance sheets competition indices are constructed, such as the Herfindahl index, and the price-cost margin for each industry. The data cover the period from 1996 to 2004, and covers 7596 service firms. Nominal values of are deflated with sector specific deflators ${ }^{15}$.

\footnotetext{
${ }^{11}$ The most highly concentrated manufacturing sector in France in 2004 was motor vehicles manufacturing, where the Herfindahl index was around $6 \%$.

${ }^{12}$ Fernandes and Paunov, 2008.

${ }^{13}$ Using firm level data I can construct service sector variables, without using any kind of arbitrary index.

1418 manufacturing sectors and 13 service industries.

${ }^{15}$ The deflators were obtained from the Eurostat Ameco dataset and EU-Klems. Operating revenues, capital stock material costs and value added were all deflated.
} 
To measure competition and to evaluate the market structure in the service sector several indicators are constructed for NACE 2-digit level ${ }^{16}$, and largely based on firm-level data. These were the price cost margin (PCM), the Herfindahl index (HHI), productivity (Index), and the minimum efficient scale (MES). Also FDI are included to control for the competitive pressure due to the presence of foreign firms.

The price cost margin (PCM) is an approximation to a firm's mark-up which can be derived directly from balance-sheet data. Tybout (2003) suggests calculating it as the difference between the production value and the total variable cost, divided by the production value. A firm's PCM can then be written as $\frac{p q-c q}{p q}=\frac{p-c}{p}$ where $c$ is the marginal cost, $p$ is the output price, and $q$ is the quantity. The PCM for firm $h$ in service industry $j$ (at NACE 4-digit aggregation level) is calculated as

$$
\begin{aligned}
P C M_{h t}^{j} & =\frac{p_{h t}^{j} q_{h t}^{j}-q_{h t}^{j} c_{h t}^{j}}{p_{h t}^{j} q_{h t}^{j}}=\frac{O R_{h t}^{j}-W_{h t}^{j}-M C_{h t}^{j}}{O R_{h t}^{j}}, \\
\widetilde{P C M_{t}^{j}} & =\sum_{h=1}^{H} P C M_{h t}^{j} * \frac{O R_{h t}^{j}}{T O T R_{h t}^{j}},
\end{aligned}
$$

where $p_{h t}^{j} q_{h t}^{j}$ are the operating revenues and $q_{h t}^{j} c_{h t}^{j}$ are the operating expenses (wages plus material costs) for firm $h$ at time $t$. In detail, $O R_{h t}^{j}$ is the operating revenues of firm $h$, while $W_{h t}^{j}$ is the wage bill, and $M C_{h t}^{j}$ material costs. Finally Equation (4.2)) was used to construct the industry's PCM as a weighted average, using the market shares $\frac{O R_{h t}^{j}}{T O T R_{h t}^{j}}$ as weights. An arithmetic mean across the $j$ sub-industries generates the PCM index for each service industry $J$. It is important to notice that the PCM approach assumes that labor and material cost are good proxies for the short-term marginal costs. Alternatively, a second proxy for the industry $J$ markup (MKUP) was constructed, using a parametric technique based on the dual Solow residual (Roeger, 1995), which is widely used in empirical applications (Konings and Vandenbussche, 2005). Using this method it is possible to evaluate the average industry mark-up as the coefficient of a parametric regression. The equation

$$
\Delta Q_{i t}=c_{i}+\mu_{0} \Delta x_{h t}+\sum_{s=1}^{S} \mu_{s} \Delta x_{h t} * t d_{s}
$$

which is a simplification of an empirical analysis by Altomonte and Barattieri (2007), was run for each $J$ industry. The dependent variable $\Delta Q_{h t}$ is output growth minus capital growth, while the left hand side $\Delta x_{h t}$ is a weighted average of the growth rates of the intermediate and labor inputs, and coefficient $\mu_{1}$ is the average mark-up. If the variable of interest interacts with the time dummies $t d_{t}$, it is possible to recover a yearly mark-up index as the sum of average markup $\mu_{1}$ plus year specific coefficient $\mu_{t}$.

A second index for the degree of competition is the Herfindahl Index (HHI) that measures market concentration. The concentration of the total market is calculated by first summing the

\footnotetext{
${ }^{16}$ All the indices were calculated at the NACE 4-digit level and were then aggregated into a simple average at the NACE 2-digit level. For notational simplicity, in this section the index $j$ refers to the NACE 4-digit level, while $J$ indicates the NACE 2-digit index, composed by aggregating the $j^{\prime} s$.
} 
operating revenues in the home market ${ }^{17}$ for each industry $j\left(T O T R_{t}^{j}\right)$.. The HHI for sector $j$ at time $t$ is then calculated as the sum of the squared values of the market shares:

$$
H H I_{t}^{j}=\sum_{h=1}^{H}\left(\frac{O R_{h t}^{j}}{T O T R_{t}^{j}}\right)^{2} .
$$

Although small firms are not in the sample, their market shares make a negligible contribution because they appear in a squared term. From another point of view the HHI index can be considered as a C4 or C25 concentration index. As a proxy for the entry barriers and economies of scale it is also used an indicator similar to HHI, called the minimum efficient scale (MES). This is calculated at industry level as

$$
M E S_{t}^{j}=\frac{\widehat{A V}_{t}^{j}}{\overline{A V}_{t}^{j}}
$$

where $M E S_{t}^{j}$ is the ratio between the average value added of the larger firms (those accounting for $50 \%$ of the industry value added $\widehat{A V}_{t}^{j}$ ) and the average value added of the smaller firms $\left(\overline{A V}_{t}^{j}\right)$. MES is a measure of the dimensional heterogeneity of the industry: the higher the index the greater are the differences in size between larger and smaller firms. The MES index is also a proxy for the optimal firm dimension in market $j$ : large MESs indicate that firms have to be large to remain in the market. In other words the higher the value of MES the higher the sunk costs associated with entry into the market, which deter potential entrants ${ }^{18}$ (Maioli et al. 2005).

My final index is a measure of turbulence (Turb), which tries to capture the degree of competition in services using the changes in firms' ranks. Firms are ranked according to their operating revenues, and Turb is calculated as the average variation in the rank of the top five: so rank variation $(\Delta$ rank) in sector $j$ is defined as the difference (in absolute term) between the position of one of the first five firms at time $t$ minus its rank at time $t-1$. If $n$ is the ranking, then the turbulence index is defined as

$$
\operatorname{Turb}_{t}^{j}=\frac{1}{5} \sum_{n=1}^{5} \Delta \operatorname{rank}_{n t}^{j} .
$$

If a new firm enters the top five immediately, because of mergers or dataset expansion, $\Delta$ rank is equal to the number of firms in industry $j$ at time $t$ in the dataset. The idea of the index is to capture the dynamic competitive pressure in the service sector; if the index is high it suggests fierce competition among firms.

Some other variables are used to describe the service sector properly. Index is a measure of service efficiency (i.e. of total factor productivity). To describe services efficiency it is not used either a parametric method (commonly used for manufacturing industries, see Olley and Pakes, 1996) or a definition of labor productivity (which can be misleading, because any improvement

\footnotetext{
${ }^{17}$ Total operating revenues minus value of exports.

${ }^{18}$ Similar to MES index there is Cost Advantage Ratio Index (CAR). A cost advantage ratio (CAR) index can be constructed using the average labor productivity instead of value added. CAR is the ratio of the labor productivity of the smaller firms (accounting for $50 \%$ of employment) to the labor productivity of larger firms (employing the other $50 \%$ of the labor force). CAR is also a measure of scale economies and in particular of long-run average costs.
} 
may be caused by an increase in value added, due to a dominant position ${ }^{19}$ ). Instead, efficiency is calculated as an index which is similar to Torniqvist index, using the definition given by Aw et al.(2001): this kind of index is commonly used to evaluate the efficiency of the service sector and in particular network industries. Let $\ln Y_{i t}, S_{i f t}, \ln X_{i f t}$, be the $\log$ of the output of firm $i$, the input $f$ as a proportion of total revenue, and the input consumption respectively, while the barred terms are the arithmetic means (for NACE 4-digit industry $j$ ) of the corresponding firm-level variables over all firms in year $t$. Then the TFP index for firm $i$ at time $t$ in sector $j$ is

$$
\begin{aligned}
\ln T F P_{i t}^{j}= & \left(\ln Y_{i t}-\ln \bar{Y}_{t}\right)+\sum_{s=2}^{t}\left(\ln \bar{Y}_{s}-\ln \bar{Y}_{s-1}\right) \\
& -\sum_{f=1}^{F} \frac{1}{2}\left(S_{i f t}+\bar{S}_{f t}\right)\left(\ln X_{i f t}-\ln \bar{X}_{f t}\right) \\
& -\sum_{s=2}^{t} \sum_{f=1}^{F} \frac{1}{2}\left(\bar{S}_{f s}+\bar{S}_{f s-1}\right)\left(\ln \bar{X}_{f s}-\ln \bar{X}_{f s-1}\right) .
\end{aligned}
$$

Here the TFP formula derives from a translog production function and the inputs considered are the tangible fixed assets, labor (labor force), and intermediate consumption. Finally variable Index is constructed as the arithmetic mean for each NACE 2-digit sector.

Another interesting indicator is based on foreign direct investment (FDI). FDI data for France is available as flow values from 1996 to 2004. Using the information provided by the EU-Klems dataset about total industry labor employment, an index of FDI intensity (FDIPW) was constructed by dividing the value of FDI flows by the total labor force for each service industry (NACE 2-digit). This was done to create comparable and homogenous FDI data among industries. FDIPW was intended to measure the effect on competition of foreign direct investment; however, as discussed above, it is not possible a priori to know whether FDI will increase or decrease the degree of competition in a given industry.

\subsection{Manufacturing Industries}

Information on 18 manufacturing industries is available at firm level from 1996 to 2004 The dataset includes all firms with operating revenues greater than 1.5 million euros; like services, there is no comparable data small firms, so the analysis is focused on medium and large firms. However this is not a severe problem, as large firms probably make most use of service inputs to the production process.

\subsubsection{Service-Manufacturing Links}

The estimated value of TFP has to be linked to the service sector variables to measure how the market structure affects firms' productivity. For this purpose it is used a standard approach which is frequently employed to evaluate empirically the spillover effects across sectors (Daveri and Silva 2004; Barba-Navaretti et al. 2004, Arnold et al. 2006). Input-output (I-O) tables show the links between the service sector and manufacturing. Since intersectoral linkages between the sectors is the main point of interest, the competition indices are aggregated across each service industry using I-O coefficients as "connectors". A competition index was created by summing across each industry using the I-O coefficients as weights to measure inter-industry effects. The coefficients assess the relative importance of service industry $j$ for manufacturing industry $m$ via

\footnotetext{
${ }^{19}$ Labor productivity is calculated as value added per worker: it is only a rough measure of efficiency for situations, as here, of highly imperfect competitive markets with entry barriers. Value added may rise because a dominant position is achieved, rather than because of a gain in efficiency.
} 
the input used. To calculate the link at time $t$ it is constructed a "service market-structure link" (SMSL) as

$$
S M S L(X)_{t}^{m}=\sum_{j}^{J} a_{m j} * X_{j t} \quad \text { on } j \text { service sectors }
$$

where $X_{j t}$ is a generic index (described in Section 5.1) for the service industry $j$ at time $t$. The $a_{m j}$ coefficients measure the service inputs that a firm in the manufacturing industry $m$ purchases on average from service industry $j$, as a proportion of total inputs Therefore $S M S L(X)_{t}^{m}$ captures the average effect of services on the manufacturing industry $m$ (which includes firm $i$ )

It is important to emphasize that the I-O coefficients are taken as constant over time. Data from the year 2000 was used to construct the I-O tables, because 2000 is in the middle of the observational period. The implicit assumption behind this is that average input mix does not change with time for each NACE 2-digit sector, so that $a_{m j}$ is a reliable mean. Besides I-O coefficients do not vary over time, with I-O tables for year 1995 and 2005, to be more precise in the interpretation of results: if the opposite were true it would not be possible to disentangle the effects of competition in services on productivity from that of changes in the technical mix of inputs (because service consumption cannot be observed for each firm). To summarize, the estimated coefficients for Equation (4.9) is expected negative, namely it will suggest a negative effect on average productivity: as long as the service sector indices rise (except Turb and Index, where the opposite is true), competition in services decreases.

\subsubsection{TFP and Input Price Bias}

The objective of this paper is to assess the impact of competition in services on the performance of manufacturing firms, or, more precisely, on manufacturing firms' total factor productivity (TFP). TFP is measured as the residual of a Cobb-Douglas production function which includes three inputs: capital, labor and materials (intermediate inputs). While revenues/sales are deflated with a wholesale deflator, and capital with a tangible fixed asset deflator, information is available for labor about the total number of employees.

There is a relevant issue about the intermediate input variable, and its price deflator, because the productivity estimation and the subsequent regressions could be seriously invalidated by unobservable input price components (Klette and Griliches, 1996) which generate bias. Even when the production function is correctly estimated, taking endogeneity into account (Olley and Pakes, 1996; Levinshon and Petrin, 2003), the problem of unobserved prices across all input and output components remains ${ }^{20}$. To illustrate the problem Cobb Douglas production function is the starting point

$$
Y_{i t}=A_{i t} K_{i t}^{\alpha_{k}} L_{i t}^{\alpha_{l}} M_{i t}^{\alpha_{z}}
$$

where the capital letters are the input and output quantities, $A_{i t}$ is the unobserved productivity, and the $\alpha$ 's are the coefficients to be estimated. Usually, using balance sheet data, values are observed but quantities are not, so the input and output values are divided by a price index to yield an approximation of the quantity. The deflated values are then a rough measure of the input and output quantities. The problem occurs if a common price deflator is used across all firms and industries, instead of observing an individual industry's price vector (or, even better,

\footnotetext{
${ }^{20}$ DeLoecker (2007) suggested an estimation technique to solve the problem of unobservable output price introducing explicitly output' imperfect competition market and demand shock in production function's estimation.
} 
individual firm's prices). To describe this problem better, it is assumed that it is possible to identify all prices except the material inputs, for which a general deflator, $c_{I}$ is used Then applying OP's method, the estimated TFP for firm $i$ is

$$
t f p_{i t}=\omega_{i t}+u_{i t}-\alpha_{m}\left(c_{i t}-c_{I t}\right),
$$

where $\omega_{i t}$ is the firm's productivity (term of interest), $u_{i t}$ is the i.i.d. error term, and $\alpha_{m}\left(c_{i t}-c_{I t}\right)$ is the bias due to the unobserved intermediate input price, and $c_{i t}$ and $c_{I t}$ are the unobserved input price and the material deflator respectively. The baseline equation used in the next section is then

$$
t f p_{i t}^{m}=\beta_{0}+\beta_{1} S M S L_{t}^{m}+\eta_{i t} .
$$

The $S M S L_{t}^{m}$ term approximates competition in services, and links services with the manufacturing sector $m$. The idea is that more competition in services increases the number of service providers and their quality, generating a positive effect on the average firm's productivity. This average effect is measured by $\beta_{1}$. Given that the estimated TFP is the dependent variable in the empirical analysis, the evaluation of the effect of competition in services on efficiency could be biased, because the estimated coefficient $\beta_{1}$ cannot disentangle the price effect from the efficiency effect, i.e.

$$
\beta_{1}=\frac{\partial t f p_{i t}}{\partial S M S L}=\frac{\partial \omega_{i t}}{\partial S M S L}-\frac{\partial \alpha_{m}\left(c_{i t}-c_{I t}\right)}{\partial S M S L} .
$$

The analysis is focused on $\frac{\partial \omega_{i t}}{\partial S M S L}$, the average effect of competition on average productivity, while $\frac{\partial \alpha_{z}\left(c_{i t}-c_{I t}\right)}{\partial S M S L}$ is the effect of competition on input prices. Therefore the coefficient $\beta_{1}$ will not only capture the efficiency effect but also the effect of competition in services on the unobserved material price. For this reasons, two different price indices are employed. First, given that the dataset provides information about firms' consumption of material (and not their consumption of services), it is calculated a composite deflator for the material input as in Arnold et al. (2006), and which is specific to each $m$ industry. Given that a large proportion of production inputs are still materials purchased from other manufacturing firms, the aim is to reduce $\left(c_{i t}-c_{I t}\right)$. Because the input prices are not directly reported by Amadeus, it is calculated the material price index as a weighted average of the output price indices $\left(d e f l_{n t}\right)$ for each manufacturing industry $n$, using the input coefficients as weights, i.e.

$$
I D_{t}^{m}=\sum_{n}^{N} \alpha_{m n} * d e f l_{n t} .
$$

The coefficient $\alpha_{m n}$ is not the same as Equation (4.9) but it is "rescaled". Now it is the ratio between manufacturing input purchase by sector $m$ to sector $n$ over the total amount manufacture purchase done by sector $m$. Then variable $I D_{t}^{m}$ it is the deflator for the material input to firm $i$ in industry $m$. This solution is not a silver bullet, but the composite deflator gives us some confidence that the $\beta_{1}$-bias generated by unobserved material prices has been reduced, since the index in Equation (4.12) is industry specific, and takes account of variations in all the input prices in manufacturing. Finally the production function is estimated separately industry by industry using the semi-parametric method described by Olley and Pakes ${ }^{21}$ (1996).

The second price term used is the price deflator for services, specific to each manufacturing industry. It is plugged directly into the TFP regressions. As argued above, such a price index is

\footnotetext{
${ }^{21}$ Recently Mairasse et al.(2008) have shown that input price bias in the estimation of production functions is not important:, as the estimations do not change when price information is included.
} 
necessary to disentangle the effects on manufacturing firms' efficiency of variation in competition from that of variation in the price of services $^{22}$.

\section{Empirical Specification}

The aim of this section is to understand if raising competition in the service market increase the productivity of the average downstream firm. To explore this, it is looked for a statistical relation between firms' TFP and the service-link variables (see Equation (4.9)), using micro data. A great advantage comes from using firm level data, because the regression can use the firms' fixed effects to capture unobserved individual heterogeneity deriving from their location, internal characteristics, etc. Additionally, with firm-level data, indices such as those described in Equation (4.9) for manufacturing can be constructed for manufacturing too, to control for the level of competition level in the intermediate-inputs market. The baseline regression estimated is a static model with fixed effects

$$
T F P_{i t}^{m}=\beta_{1} S S C(X)_{t}^{m}+\sum_{f=1}^{F} \beta_{f} F_{f i t}^{m}+\beta_{h} H H I(M)_{t}^{m}+P(S)_{m t}+D_{t}+c_{i}+\varepsilon_{i t}
$$

where $T F P_{i t}^{m}$ is the total factor productivity of manufacturing firm $i$ in industry $m$ at time $t$, and $S M S L(X)_{t}^{m}$ is the constructed variable of interest which relates the service industry's market-structure to the manufacturing sectors It is important to notice that the effect of $S M S L(X)_{t}^{m}$ is not at firm level but at industry level (NACE 2-digit), so the estimated coefficient $\beta_{1}$ has to be interpreted as the effect of competition in services on the average productivity of the manufacturing industry, or, as it is showed in Section $4, \beta_{1}$ is $\frac{\partial \overline{T F P}}{\partial s}$. Here, like Arnold et al. (2004), but unlike Fernandes and Paunov (2008), the variable of interest is defined on the same time period as the dependent variable. Even if lagged variables were used, the results would be the same. In addition the firm-level control variables ${ }^{23}\left(F_{i t}^{m}\right)$ are added, such as the $\log$ of capital intensity ${ }^{24}(\operatorname{Ln}(\mathrm{KL}))$, the export status ${ }^{25}$ dummy (Export), and the wage bill as proportion of total revenues (LabC), to the estimation.

Since the majority of inputs come from the other manufacturing industries, it is introduced $H H I(M)_{t}^{m}$ which captures the effect of competition in the manufacturing input market, into the regression. $H H I(M)_{t}^{m}$ is constructed according to Equation (4.9) where the $X_{j t}$ term is the concentration index ${ }^{26}$ (Herfindahl index).

It is also included in the regression a proxy for services, the input price $P(S)_{m t}$, that is an input service deflator ${ }^{27}$, specific to each manufacturing industry. As discussed in the previous section, the price index is included among the regressors, such that the coefficient $\beta_{1}$

\footnotetext{
${ }^{22}$ If the cost of service inputs decreases, the consumption of services rises, but the marginal productivity of services shrinks. Then the effect on TFP is unknown: it can either increase or decrease.

${ }^{23}$ I also used the average wage and the firm's PCM, as defined in Equation (4.1), as control variables. The coefficients are not significant and the final conclusions do not change. The PCM was employed to control for potential gains in productivity due to firm mark-ups, i.e. potential gains derived from extra profits (Konings and Vandenbussche, 2008).

${ }^{24}$ Tangible fixed assets divided by total employment of labor.

${ }^{25}$ This variable is included to explore whether trading activity affects productivity (Clerides, Leach, Tybout, 1998). I also included Export among the state variables used in the estimation of the production function to control for learning through the exporting process (De Loecker, 2007). The results do not depend on which of with the two measures of TFP is used.

${ }^{26}$ I also controlled for other proxies, such as the industry-average PCM. A specific price deflator was included in the estimation of TFP, to take price variation in the manufacturing input market into account.

${ }^{27}$ EU-KLEMS database.
} 
(Equation 4.11a) captures the effect of competition on firms' efficiency, and not the effect of price variation. Finally $c_{i}$ is the unobserved heterogeneity, $\varepsilon_{i t}$ is the idiosyncratic error term, and $D_{t}$ are year dummies to control for business cycles. Table ?? presents the results obtained with OLS regressions for all the service industries aggregated together (the $\mathrm{S}$ in parenthesis); it gives the flavor of the relationship.

Table 5.1: Baseline OLS regression ${ }^{\ddagger}$.

\begin{tabular}{|c|c|c|c|c|c|c|c|}
\hline & $\begin{array}{c}(1) \\
T F P_{i m t}\end{array}$ & $\begin{array}{c}(2) \\
T F P_{i m t}\end{array}$ & $\begin{array}{c}(3) \\
T F P_{i m t}\end{array}$ & $\begin{array}{c}(4) \\
T F P_{i m t}\end{array}$ & $\begin{array}{c}(5) \\
T F P_{i m t}\end{array}$ & $\begin{array}{c}(6) \\
T F P_{i m t}\end{array}$ & $\begin{array}{c}(7) \\
T F P_{i m t}\end{array}$ \\
\hline $\operatorname{Price}(\mathrm{S})_{m t}$ & $\begin{array}{c}0.031^{* * *} \\
{[0.006]}\end{array}$ & $\begin{array}{c}0.007 \\
{[0.006]}\end{array}$ & $\begin{array}{l}0.010^{*} \\
{[0.006]}\end{array}$ & $\begin{array}{l}-0.002 \\
{[0.006]}\end{array}$ & $\begin{array}{c}-0.018^{* * *} \\
{[0.006]}\end{array}$ & $\begin{array}{c}-0.032 * * * \\
{[0.006]}\end{array}$ & $\begin{array}{c}-0.040 * * * \\
{[0.006]}\end{array}$ \\
\hline $\mathrm{FDIPW}(\mathrm{S})_{m t}$ & $\begin{array}{c}1.749 * * * \\
{[0.037]}\end{array}$ & $\begin{array}{c}2.007 * * * \\
{[0.037]}\end{array}$ & $\begin{array}{c}2.221 * * * \\
{[0.041]}\end{array}$ & $\begin{array}{c}1.564 * * * \\
{[0.038]}\end{array}$ & $\begin{array}{c}1.291 * * * \\
{[0.036]}\end{array}$ & $\begin{array}{c}0.473 * * * \\
{[0.039]}\end{array}$ & $\begin{array}{c}1.490 * * * \\
{[0.043]}\end{array}$ \\
\hline $\mathrm{HHI}(\mathrm{S})_{m t}$ & $\begin{array}{c}-25.783^{* * *} \\
{[0.629]}\end{array}$ & & & & & & $\begin{array}{c}36.155^{* * *} \\
{[1.591]}\end{array}$ \\
\hline $\mathrm{PCM}(\mathrm{S})_{m t}$ & & $\begin{array}{c}-20.786^{* * *} \\
{[0.398]}\end{array}$ & & & & & $\begin{array}{c}-6.492^{* * *} * \\
{[1.491]}\end{array}$ \\
\hline $\operatorname{MES}(\mathrm{S})_{m t}$ & & & $\begin{array}{c}-0.552^{* * *} \\
{[0.012]}\end{array}$ & & & & $\begin{array}{c}-1.300 * * * \\
{[0.060]}\end{array}$ \\
\hline $\operatorname{MKUP}(\mathrm{S})_{m t}$ & & & & $\begin{array}{c}-1.069 * * * \\
{[0.058]}\end{array}$ & & & \\
\hline $\operatorname{TURB}(\mathrm{S})_{m t}$ & & & & & $\begin{array}{c}-0.006^{* *} \\
{[0.003]}\end{array}$ & & \\
\hline $\operatorname{INDEX}(\mathrm{S})_{m t}$ & & & & & & $\begin{array}{c}10.066^{* * *} \\
{[0.364]}\end{array}$ & $\begin{array}{c}20.136^{* * *} \\
{[0.441]}\end{array}$ \\
\hline $\mathrm{HHI}(\mathrm{M})_{m t}$ & $\begin{array}{c}-9.919 * * * \\
{[0.228]}\end{array}$ & $\begin{array}{c}-8.647 * * * \\
{[0.231]}\end{array}$ & $\begin{array}{c}-9.574 * * * \\
{[0.228]}\end{array}$ & $\begin{array}{c}-10.208^{* * *} \\
{[0.230]}\end{array}$ & $\begin{array}{c}-10.945^{* * *} \\
{[0.230]}\end{array}$ & $\begin{array}{c}-10.478^{* * *} \\
{[0.235]}\end{array}$ & $\begin{array}{c}-7.617^{* * *} * \\
{[0.238]}\end{array}$ \\
\hline $\operatorname{Exdum}_{i m t-1}$ & $\begin{array}{c}0.106^{* * *} \\
{[0.008]}\end{array}$ & $\begin{array}{c}0.091^{* * * *} \\
{[0.008]}\end{array}$ & $\begin{array}{c}0.090^{* * *} * \\
{[0.008]}\end{array}$ & $\begin{array}{c}0.093^{* * *} \\
{[0.008]}\end{array}$ & $\begin{array}{c}0.089 * * * \\
{[0.008]}\end{array}$ & $\begin{array}{c}0.094^{* * *} \\
{[0.008]}\end{array}$ & $\begin{array}{c}0.077^{* * * *} \\
{[0.008]}\end{array}$ \\
\hline $\operatorname{Ln}(\mathrm{KL})_{i m t-1}$ & $\begin{array}{c}0.115^{* * *} \\
{[0.004]}\end{array}$ & $\begin{array}{c}0.125^{* * * *} \\
{[0.004]}\end{array}$ & $\begin{array}{c}0.121^{* * *} \\
{[0.004]}\end{array}$ & $\begin{array}{c}0.105^{* * *} \\
{[0.004]}\end{array}$ & $\begin{array}{c}0.096 * * * \\
{[0.004]}\end{array}$ & $\begin{array}{c}0.088^{* * *} * \\
{[0.004]}\end{array}$ & $\begin{array}{c}0.123^{* * *} \\
{[0.004]}\end{array}$ \\
\hline $\mathrm{LabC}_{i m t-1}$ & $\begin{array}{c}1.508^{* * * *} \\
{[0.020]}\end{array}$ & $\begin{array}{c}1.505^{* * * *} \\
{[0.020]}\end{array}$ & $\begin{array}{c}1.519^{* * * *} \\
{[0.020]}\end{array}$ & $\begin{array}{c}1.523^{* * *} \\
{[0.020]}\end{array}$ & $\begin{array}{c}1.510^{* * *} * \\
{[0.020]}\end{array}$ & $\begin{array}{c}1.481^{* * * *} \\
{[0.020]}\end{array}$ & $\begin{array}{c}1.473^{* * *} \\
{[0.020]}\end{array}$ \\
\hline $\begin{array}{l}\text { Obs } \\
R^{2}\end{array}$ & $\begin{array}{l}51692 \\
0.201\end{array}$ & $\begin{array}{l}51692 \\
0.211\end{array}$ & $\begin{array}{l}51692 \\
0.205\end{array}$ & $\begin{array}{l}51689 \\
0.190\end{array}$ & $\begin{array}{l}51692 \\
0.185\end{array}$ & $\begin{array}{l}51692 \\
0.197\end{array}$ & $\begin{array}{l}51692 \\
0.240\end{array}$ \\
\hline
\end{tabular}

$\ddagger$ Ordinary Least Sqaure. Robust standard error, clusterd by sector, are in squared brackets. Time dummies included.

As expected, manufacturing productivity (TFP) increases as competition in services increases. It is interesting to notice that FDI intensity (FDIPW) is positively related to firms' TFP, as is the average efficiency in the service sector (Index). The other results are quite intuitive. For example, the positive signs of $\operatorname{Ln}(\mathrm{KL})$ and export status: however the cost of labor (LabC) also has a positive coefficient, which is a bit puzzling

Nonetheless the estimation of Equation (5.1) may be problematic if there is unobserved heterogeneity among the firms; one potential solution may be to implement a fixed-effect estimator. However the variables in the equation are likely to be jointly endogenous. In particular the $F_{i t}^{m}$ variables can be endogenous because of simultaneity or to two-way causality with dependent variable: moreover the Equation (5.1) could fail in the strict exogeneity assumption, given that productivity can be dependent on its past realizations, and $F_{i t}^{m}$ variables are lagged by one period. The presence of endogenous variables and the state dependency for firms' TFP will bias the estimates of the coefficients. To address these problems it is used the dynamic panel estimation technique developed by Arellano and Bond (1991), and the system-GMM procedure presented by Blundell and Bond (1998).A concern arises with the GMM estimator if there is no evidence of firm-specific effects, in which case it is more efficient to estimate the equation in levels (using 
lagged levels as instruments) than in first differences. However several tests suggest the existence of fixed effects ${ }^{28}$. Then the estimated equation is similar to Equation (5.1), i.e.

$T F P_{i t}^{m}=\beta_{0} T F P_{i t-1}^{m}+\beta_{1} S M S L(X)_{t}^{m}+\sum_{f=1}^{F} \beta_{f} F_{f i t-1}^{m}+H H I(M)_{t}^{m}+P(S)_{m t}+D_{t}+c_{i}+\varepsilon_{i t}$

In a nutshell, the system GMM is composed by a system of two equations ${ }^{29}$ : an equation in first differences and a second one in levels. First-differences are used to eliminate the firm-specific effects, and then lagged levels of the variables are employed as instruments. Then an equation in levels is added, and the variables in each level are instrumented by variables in differences.

\section{Results}

This Section will discuss the results of the empirical analysis ${ }^{30}$. The first set of tables (Tables 6.1 and 6) show the results where regressor $S M S L(X)_{t}^{m}(4.9)$ is constructed using all 13 service sectors. The estimator implemented is "system-GMM" in order to take into account the endogeneity of firms' control variables and state dependency; the TFP is lagged by two periods to get rid of serial correlation in the error term ${ }^{31}$. Finally sector dummies are not included because large part of regressors $S M S L(X)_{t}^{m}$ are at sector level too, and sector dummies would have not added anything to the estimation.

Table 6.1 shows the estimation results using $S M S L_{t}^{m}$ (4.9) which includes the aggregated service-sector variables( $\mathrm{S}$ in parenthesis). The regressors used to proxy competition in services were the FDI per worker (FDIPW), plus all the competition proxies separately: the indices used have to be interpreted as the inverse of the degree of competition. When the PCM or the HHI rises, the degree of competition decreases. It is evident that the average mark-up in the service sector (with either definition) has a negative effect on average productivity; as expected more market power in upstream firms can reduce the competitiveness of downstream firms. The coefficient of the concentration index (HHI), is also significant and negative: therefore on average more concentration in services has a negative effect on firms' efficiency. The proxy for scale economies (MES) also has a negative sign and is significant, as expected: larger entry barriers reduce the productivity of downstream firms. If the PCM or HHI index grows by $1 \%$ the average firms' productivity decreases by $1.9 \%$ and $1.3 \%$ respectively. Further considerations come from other service variables. The Index coefficient is positive but not significant. FDIPW has a positive effect on manufacturing firms' efficiency: it seems that the FDI intensity enhances competition, and does not have a substitution effect with national incumbents. Finally, the service price coefficient (Price $(\mathrm{S})$ ) is negative but not significant for all specifications: with the introduction of the service price index into the regression, FDI can capture the technical spillover

\footnotetext{
${ }^{28}$ I test for the presence of first-order serial correlation, which indicate the presence of unobserved firm-specific effects. Then Mundalak test, introduced by Wooldridge (2002), indicates that fixed effect estimator is better than random effects.

${ }^{29}$ System GMM by Blundell Bond (1998) is advised if the autoregressive term of dependent variable $\left(\beta_{0}\right)$ is close to one. In this case I run a simple OLS regression of actual TFP value on past value and $\beta_{1}$ was 0.95 . In addition with first difference GMM the Hansen and Sargan Test test do not pass for several specifications (also with orthogonal deviations).

${ }^{30}$ The sample used in the analysis is a reduced sample. I consider $98 \%$ of firms, excluding those which had growth rates of TFP below the 1 st and above the 99 th centile.

${ }^{31}$ The lags used as instruments do not change across different specifications: they vary from the second lag up to the end of available observations. In addition one step estimator is used to avoid correction for robust standard errors. Two step estimator gives similar results.
} 
Table 6.1: Aggregated Services - Baseline Equation ${ }^{\ddagger}$.

\begin{tabular}{|c|c|c|c|c|c|c|c|}
\hline & $\begin{array}{c}(1) \\
T F P_{i m t}\end{array}$ & $\begin{array}{c}(2) \\
T F P_{i m t}\end{array}$ & $\begin{array}{c}(3) \\
T F P_{i m t}\end{array}$ & $\begin{array}{c}(4) \\
T F P_{i m t}\end{array}$ & $\begin{array}{c}(5) \\
T F P_{i m t}\end{array}$ & $\begin{array}{c}(6) \\
T F P_{i m t}\end{array}$ & $\begin{array}{c}(7) \\
T F P_{i m t}\end{array}$ \\
\hline $\mathrm{TFP}_{i m t-1}$ & $\begin{array}{c}0.746^{* * *} \\
{[0.083]}\end{array}$ & $\begin{array}{c}0.746^{* * *} \\
{[0.083]}\end{array}$ & $\begin{array}{c}0.751^{* * *} \\
{[0.083]}\end{array}$ & $\begin{array}{c}0.752^{* * *} \\
{[0.084]}\end{array}$ & $\begin{array}{c}0.749^{* * *} \\
{[0.083]}\end{array}$ & $\begin{array}{c}0.735^{* * *} \\
{[0.084]}\end{array}$ & $\begin{array}{c}0.733^{* * *} \\
{[0.084]}\end{array}$ \\
\hline $\mathrm{TFP}_{i m t-2}$ & $\begin{array}{c}0.232^{* * *} \\
{[0.084]}\end{array}$ & $\begin{array}{c}0.234^{* * *} \\
{[0.084]}\end{array}$ & $\begin{array}{c}0.231^{* * *} \\
{[0.084]}\end{array}$ & $\begin{array}{c}0.226^{* * *} \\
{[0.085]}\end{array}$ & $\begin{array}{c}0.226^{* * *} * \\
{[0.084]}\end{array}$ & $\begin{array}{c}0.234^{* * *} \\
{[0.084]}\end{array}$ & $\begin{array}{c}0.240^{* * *} * \\
{[0.084]}\end{array}$ \\
\hline $\operatorname{Price}(\mathrm{S})_{m t}$ & $\begin{array}{l}-0.007 \\
{[0.004]}\end{array}$ & $\begin{array}{c}-0.009^{* *} \\
{[0.004]}\end{array}$ & $\begin{array}{l}-0.007 \\
{[0.004]}\end{array}$ & $\begin{array}{c}-0.009^{* *} \\
{[0.005]}\end{array}$ & $\begin{array}{c}-0.012^{* *} \\
{[0.005]}\end{array}$ & $\begin{array}{c}-0.012^{* *} \\
{[0.005]}\end{array}$ & $\begin{array}{c}-0.010^{* *} \\
{[0.005]}\end{array}$ \\
\hline $\mathrm{FDIPW}(\mathrm{S})_{m t}$ & $\begin{array}{c}0.057 * * * \\
{[0.020]}\end{array}$ & $\begin{array}{c}0.067 * * * \\
{[0.021]}\end{array}$ & $\begin{array}{c}0.071 * * * \\
{[0.023]}\end{array}$ & $\begin{array}{c}0.051 * * * \\
{[0.020]}\end{array}$ & $\begin{array}{c}0.037 * * \\
{[0.017]}\end{array}$ & $\begin{array}{c}0.036^{* * * *} \\
{[0.011]}\end{array}$ & $\begin{array}{c}0.067 * * * \\
{[0.019]}\end{array}$ \\
\hline $\mathrm{HHI}(\mathrm{S})_{m t}$ & $\begin{array}{c}-1.861 * * * \\
{[0.513]}\end{array}$ & & & & & & $\begin{array}{c}0.326 \\
{[0.717]}\end{array}$ \\
\hline $\mathrm{PCM}(\mathrm{S})_{m t}$ & & $\begin{array}{c}-1.271 * * * \\
{[0.310]}\end{array}$ & & & & & $\begin{array}{c}-0.711^{*} \\
{[0.404]}\end{array}$ \\
\hline $\operatorname{MES}(\mathrm{S})_{m t}$ & & & $\begin{array}{c}-0.031^{* * *} \\
{[0.009]}\end{array}$ & & & & $\begin{array}{l}-0.040 \\
{[0.032]}\end{array}$ \\
\hline $\operatorname{MKUP}(\mathrm{S})_{m t}$ & & & & $\begin{array}{c}-0.095 * * * \\
{[0.034]}\end{array}$ & & & \\
\hline $\operatorname{TURB}(\mathrm{S})_{m t}$ & & & & & $\begin{array}{l}-0.001 \\
{[0.001]}\end{array}$ & & \\
\hline $\operatorname{Index}(\mathrm{S})_{m t}$ & & & & & & $\begin{array}{c}0.079 \\
{[0.191]}\end{array}$ & $\begin{array}{l}0.671^{*} \\
{[0.403]}\end{array}$ \\
\hline $\mathrm{HHI}(\mathrm{M})_{m t}$ & $\begin{array}{l}-0.043 \\
{[0.161]}\end{array}$ & $\begin{array}{c}0.045 \\
{[0.154]}\end{array}$ & $\begin{array}{l}-0.015 \\
{[0.161]}\end{array}$ & $\begin{array}{l}-0.061 \\
{[0.162]}\end{array}$ & $\begin{array}{l}-0.137 \\
{[0.172]}\end{array}$ & $\begin{array}{l}-0.188 \\
{[0.165]}\end{array}$ & $\begin{array}{c}0.019 \\
{[0.142]}\end{array}$ \\
\hline Exdum $_{i m t-1}$ & $\begin{array}{l}-0.004 \\
{[0.016]}\end{array}$ & $\begin{array}{l}-0.003 \\
{[0.016]}\end{array}$ & $\begin{array}{l}-0.004 \\
{[0.016]}\end{array}$ & $\begin{array}{l}-0.002 \\
{[0.016]}\end{array}$ & $\begin{array}{l}-0.002 \\
{[0.016]}\end{array}$ & $\begin{array}{l}-0.002 \\
{[0.016]}\end{array}$ & $\begin{array}{l}-0.003 \\
{[0.016]}\end{array}$ \\
\hline $\operatorname{Ln}(\mathrm{KL})_{i m t-1}$ & $\begin{array}{c}0.025^{* * *} \\
{[0.009]}\end{array}$ & $\begin{array}{c}0.025^{* * *} \\
{[0.009]}\end{array}$ & $\begin{array}{c}0.020^{* *} \\
{[0.009]}\end{array}$ & $\begin{array}{c}0.025^{* * *} \\
{[0.010]}\end{array}$ & $\begin{array}{c}0.026^{* * *} \\
{[0.010]}\end{array}$ & $\begin{array}{c}0.025^{* * *} \\
{[0.010]}\end{array}$ & $\begin{array}{c}0.025 * * * \\
{[0.009]}\end{array}$ \\
\hline $\mathrm{LabC}_{i m t-1}$ & $\begin{array}{l}-0.019 \\
{[0.066]}\end{array}$ & $\begin{array}{l}-0.024 \\
{[0.066]}\end{array}$ & $\begin{array}{l}-0.026 \\
{[0.067]}\end{array}$ & $\begin{array}{l}-0.020 \\
{[0.067]}\end{array}$ & $\begin{array}{l}-0.018 \\
{[0.066]}\end{array}$ & $\begin{array}{l}-0.024 \\
{[0.067]}\end{array}$ & $\begin{array}{l}-0.031 \\
{[0.067]}\end{array}$ \\
\hline Obs & 39912 & 39912 & 39912 & 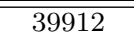 & 39912 & 39912 & 39912 \\
\hline Firms & 8731 & 8731 & 8731 & 8731 & 8731 & 8731 & 8731 \\
\hline Instr. & 8731 & 99 & 99 & 99 & 99 & 99 & 102 \\
\hline Hansen Test & 0.353 & 0.401 & 0.306 & 0.406 & 0.393 & 0.363 & 0.385 \\
\hline Hansen Test Lev & 0.640 & 0.664 & 0.582 & 0.618 & 0.665 & 0.659 & 0.710 \\
\hline AR2 Test & 0.231 & 0.219 & 0.238 & 0.259 & 0.257 & 0.217 & 0.196 \\
\hline
\end{tabular}

$\ddagger$ System GMM estimation. Robust standard errors in squared brackets. Time dummies included both as variables and instruments. One step estimator used. Significance level: * is the p-value $>0.1, * *$ is the $\mathrm{p}$-value $>0.05$, and $* * *$ is the p-value $>0.01$. Instr: total number of instruments. Lev: Hansen test for the equation in levels.

effect from services to manufacturing sectors (backward spillover). In Column (7) all the indices are plugged into the estimation together. The significance of some of the individual coefficients decreases, probably because the indices are highly inter-correlated. The degree of competition in manufacturing $\mathrm{HHI}(\mathrm{M})$ does not affect firms' efficiency. The firms' control variables are all considered endogenous, and only the capital intensity, as expected, has a significant effect on productivity.

An interesting extension may be the existence of non-linear effects of competition in services. In other words, an excess of liberalization and deregulation in the upstream market was predicted to harm the average productivity in downstream markets. Table 6 shows the results of estimating Equation(5.2) with the introduction of quadratic terms for PCM, HHI, Turb, and MES.

We see that only the first two columns give interesting results. The sign of the variables changes, and they become negative in the squared term: only HHI and PCM are significant, and even these terms are not strongly significant. This supports the hypothesis that an excess of 
Table 6.2: Aggregated Services - Quadratic Term ${ }^{\ddagger}$.

\begin{tabular}{|c|c|c|c|c|}
\hline & $\begin{array}{c}(1) \\
T F P_{i m t}\end{array}$ & $\begin{array}{c}(2) \\
T F P_{i m t}\end{array}$ & $\begin{array}{c}(3) \\
T F P_{i m t}\end{array}$ & $\begin{array}{c}(4) \\
T F P_{i m t}\end{array}$ \\
\hline $\mathrm{TFP}_{i m t-1}$ & $\begin{array}{c}0.730^{* * *} \\
{[0.084]}\end{array}$ & $\begin{array}{c}0.728^{* * *} \\
{[0.084]}\end{array}$ & $\begin{array}{c}0.747^{* * *} \\
{[0.083]}\end{array}$ & $\begin{array}{c}0.746^{* * *} \\
{[0.084]}\end{array}$ \\
\hline $\mathrm{TFP}_{i m t-2}$ & $\begin{array}{c}0.244^{* * *} \\
{[0.084]}\end{array}$ & $\begin{array}{c}0.249 * * * \\
{[0.085]}\end{array}$ & $\begin{array}{c}0.228 * * * \\
{[0.084]}\end{array}$ & $\begin{array}{c}0.237^{* * * *} \\
{[0.085]}\end{array}$ \\
\hline $\operatorname{Price}(\mathrm{S})_{m t}$ & $\begin{array}{l}-0.002 \\
{[0.005]}\end{array}$ & $\begin{array}{l}-0.007 \\
{[0.005]}\end{array}$ & $\begin{array}{c}-0.011^{* *} \\
{[0.005]}\end{array}$ & $\begin{array}{l}-0.001 \\
{[0.007]}\end{array}$ \\
\hline $\mathrm{FDIPW}(\mathrm{S})_{m t}$ & $\begin{array}{c}0.025 \\
{[0.026]}\end{array}$ & $\begin{array}{c}0.055^{* *} \\
{[0.022]}\end{array}$ & $\begin{array}{c}0.027 \\
{[0.025]}\end{array}$ & $\begin{array}{c}0.035 \\
{[0.038]}\end{array}$ \\
\hline $\mathrm{HHI}(\mathrm{S})_{m t}$ & $\begin{array}{c}16.021^{*} \\
{[8.953]}\end{array}$ & & & \\
\hline $\mathrm{HHI}(\mathrm{S})_{m t}^{2}$ & $\begin{array}{c}-447.401^{* *} \\
{[222.538]}\end{array}$ & & & \\
\hline $\operatorname{PCM}(\mathrm{S})_{m t}$ & & $\begin{array}{l}7.344^{*} \\
{[4.157]}\end{array}$ & & \\
\hline $\mathrm{PCM}(\mathrm{S})_{m t}^{2}$ & & $\begin{array}{c}-97.763^{* *} \\
{[46.997]}\end{array}$ & & \\
\hline $\operatorname{Turb}(\mathrm{S})_{m t}$ & & & $\begin{array}{c}0.004 \\
{[0.008]}\end{array}$ & \\
\hline $\operatorname{Turb}(\mathrm{S})_{m t}^{2}$ & & & $\begin{array}{l}-0.0001 \\
{[0.000]}\end{array}$ & \\
\hline $\operatorname{MES}(\mathrm{S})_{m t}$ & & & & $\begin{array}{c}0.364 \\
{[0.373]}\end{array}$ \\
\hline $\operatorname{MES}(\mathrm{S})_{m t}^{2}$ & & & & $\begin{array}{l}-0.105 \\
{[0.099]}\end{array}$ \\
\hline $\mathrm{HHI}(\mathrm{M})_{m t}$ & $\begin{array}{l}-0.143 \\
{[0.172]}\end{array}$ & $\begin{array}{l}-0.012 \\
{[0.158]}\end{array}$ & $\begin{array}{l}-0.135 \\
{[0.172]}\end{array}$ & $\begin{array}{c}0.033 \\
{[0.160]}\end{array}$ \\
\hline Exdum $_{i m t-1}$ & $\begin{array}{l}-0.003 \\
{[0.016]}\end{array}$ & $\begin{array}{l}-0.001 \\
{[0.016]}\end{array}$ & $\begin{array}{l}-0.002 \\
{[0.016]}\end{array}$ & $\begin{array}{l}-0.003 \\
{[0.016]}\end{array}$ \\
\hline $\operatorname{Ln}(\mathrm{KL})_{i m t-1}$ & $\begin{array}{c}0.029 * * * \\
{[0.010]}\end{array}$ & $\begin{array}{c}0.027^{* * *} \\
{[0.009]}\end{array}$ & $\begin{array}{c}0.026^{* * *} \\
{[0.010]}\end{array}$ & $\begin{array}{c}0.024^{* *} \\
{[0.010]}\end{array}$ \\
\hline $\mathrm{LabC}_{i m t-1}$ & $\begin{array}{l}-0.019 \\
{[0.067]} \\
\end{array}$ & $\begin{array}{l}-0.026 \\
{[0.067]} \\
\end{array}$ & $\begin{array}{l}-0.018 \\
{[0.066]}\end{array}$ & $\begin{array}{l}-0.028 \\
{[0.067]}\end{array}$ \\
\hline Obs & 39912 & 39912 & 39912 & 39912 \\
\hline Firms & 8731 & 8731 & 8731 & 8731 \\
\hline Instr. & 99 & 99 & 99 & 99 \\
\hline Hansen Test & 0.382 & 0.422 & 0.376 & 0.295 \\
\hline Hansen Test Lev. & 0.686 & 0.741 & 0.632 & 0.594 \\
\hline AR2 Test & 0.193 & 0.167 & 0.245 & 0.213 \\
\hline
\end{tabular}

¥ System GMM estimation. Robust standard errors in squared brackets. Time dummies included both as variables and instruments. One step estimator used. Significance level: $*$ is the p-value $>0.1,{ }^{* *}$ is the $\mathrm{p}$-value $>0.05$, and $* * *$ is the p-value $>0.01$. Instr: total number of instruments. Lev: Hansen test for the equation in levels.

competition is harmful. This may depend on the characteristics of the service industries, which in some cases, such as networks, need large dimensions or some degree of market power to recover the huge investments they have had to make, or to exploit economies of scale. Prices and FDI do not change their sign, but they are no longer strongly significant.

Despite these results, which appear to support my hypotheses, it is necessary to be careful with their interpretation for one simple reason: the variable $S M S L_{t}^{m}$ includes within itself the characteristics of a variety of heterogeneous service industries, and so the coefficients embody the features of all these industries. For example, land transport (60) has high natural barrier and different regulation from the financial intermediation (65) industry; the number of competitors 
in the telecommunications sector is much smaller than the number of firms in the retailing sector; etc. Additionally, there are many firms in sectors such as retailing and other business services which are not included in the data, because they are too small. For these reasons, another set of regressions are estimated, with a different aggregation level in the competition indices (see Equation(4.9)). Cross-sectional linkages are constructed for the network industries ${ }^{32}$ only. Network industries are chosen because these are characterized by high fixed costs and a low level of competition. In addition, given the average size of the businesses in the industry, the dataset for network services is quite representative of the entire population. Table 6 presents the results of the GMM estimation using the indices relating to the network industries only. The corresponding OLS results are shown in Table D.

Table 6.3: Network Services - Baseline Equation ${ }^{\ddagger}$.

\begin{tabular}{|c|c|c|c|c|c|c|c|}
\hline & $\begin{array}{c}(1) \\
T F P_{i m t}\end{array}$ & $\begin{array}{c}(2) \\
T F P_{i m t}\end{array}$ & $\begin{array}{c}(3) \\
T F P_{i m t}\end{array}$ & $\begin{array}{c}(4) \\
T F P_{i m t}\end{array}$ & $\begin{array}{c}(5) \\
T F P_{i m t}\end{array}$ & $\begin{array}{c}(6) \\
T F P_{i m t}\end{array}$ & $\begin{array}{c}(7) \\
T F P_{i m t}\end{array}$ \\
\hline $\mathrm{TFP}_{i m t-1}$ & $\begin{array}{c}0.739^{* * *} \\
{[0.083]}\end{array}$ & $\begin{array}{c}0.743^{* * *} \\
{[0.082]}\end{array}$ & $\begin{array}{c}0.738^{* * *} \\
{[0.082]}\end{array}$ & $\begin{array}{c}0.739 * * * \\
{[0.083]}\end{array}$ & $\begin{array}{c}0.751^{* * *} \\
{[0.083]}\end{array}$ & $\begin{array}{c}0.721^{* * *} \\
{[0.084]}\end{array}$ & $\begin{array}{c}0.716^{* * *} \\
{[0.083]}\end{array}$ \\
\hline $\mathrm{TFP}_{i m t-2}$ & $\begin{array}{c}0.232^{* * * *} \\
{[0.083]}\end{array}$ & $\begin{array}{c}0.229 * * * \\
{[0.083]}\end{array}$ & $\begin{array}{c}0.234^{* * *} \\
{[0.083]}\end{array}$ & $\begin{array}{c}0.234^{* * * *} \\
{[0.083]}\end{array}$ & $\begin{array}{c}0.221^{* * *} \\
{[0.084]}\end{array}$ & $\begin{array}{c}0.241^{* * *} \\
{[0.084]}\end{array}$ & $\begin{array}{c}0.247^{* * * *} \\
{[0.083]}\end{array}$ \\
\hline $\operatorname{Price}(\mathrm{N})_{m t}$ & $\begin{array}{c}-0.323^{* * *} \\
{[0.090]}\end{array}$ & $\begin{array}{c}-0.252^{* * *} \\
{[0.093]}\end{array}$ & $\begin{array}{c}-0.258^{* * *} \\
{[0.094]}\end{array}$ & $\begin{array}{c}-0.304^{* * *} \\
{[0.089]}\end{array}$ & $\begin{array}{c}-0.348^{* * *} \\
{[0.104]}\end{array}$ & $\begin{array}{c}-0.557^{* * *} \\
{[0.141]}\end{array}$ & $\begin{array}{c}-0.581 * * * \\
{[0.161]}\end{array}$ \\
\hline $\mathrm{FDIPW}(\mathrm{N})_{m t}$ & $\begin{array}{c}0.066^{* * *} \\
{[0.020]}\end{array}$ & $\begin{array}{c}0.069^{* * *} \\
{[0.021]}\end{array}$ & $\begin{array}{c}0.068^{* * *} \\
{[0.021]}\end{array}$ & $\begin{array}{c}0.065^{* * *} \\
{[0.020]}\end{array}$ & $\begin{array}{c}0.069^{* * *} \\
{[0.021]}\end{array}$ & $\begin{array}{c}0.107^{* * *} \\
{[0.030]}\end{array}$ & $\begin{array}{c}0.121^{* * *} \\
{[0.032]}\end{array}$ \\
\hline $\mathrm{HHI}(\mathrm{N})_{m t}$ & $\begin{array}{c}-1.464^{* *} \\
{[0.581]}\end{array}$ & & & & & & $\begin{array}{c}-5.269^{* * * *} \\
{[1.442]}\end{array}$ \\
\hline $\operatorname{PCM}(\mathrm{N})_{m t}$ & & $\begin{array}{c}-1.533^{* * *} \\
{[0.545]}\end{array}$ & & & & & $\begin{array}{c}-1.193^{* *} \\
{[0.552]}\end{array}$ \\
\hline $\operatorname{MES}(\mathrm{N})_{m t}$ & & & $\begin{array}{c}-0.040^{*} \\
{[0.022]}\end{array}$ & & & & $\begin{array}{l}0.058^{*} \\
{[0.035]}\end{array}$ \\
\hline $\operatorname{MKUP}(\mathrm{N})_{m t}$ & & & & $\begin{array}{c}-0.125^{* *} \\
{[0.057]}\end{array}$ & & & \\
\hline $\operatorname{TURB}(\mathrm{N})_{m t}$ & & & & & $\begin{array}{l}-0.002 \\
{[0.002]}\end{array}$ & & \\
\hline $\operatorname{INDEX}(\mathrm{N})_{m t}$ & & & & & & $\begin{array}{c}2.310^{* *} \\
{[0.915]}\end{array}$ & $\begin{array}{c}4.292^{* * *} \\
{[1.323]}\end{array}$ \\
\hline $\mathrm{HHI}(\mathrm{M})_{m t}$ & $\begin{array}{c}-0.673^{* * *} * \\
{[0.259]}\end{array}$ & $\begin{array}{c}-0.619 * * \\
{[0.252]}\end{array}$ & $\begin{array}{c}-0.628^{* *} \\
{[0.253]}\end{array}$ & $\begin{array}{c}-0.619 * * \\
{[0.253]}\end{array}$ & $\begin{array}{c}-0.607^{* *} \\
{[0.258]}\end{array}$ & $\begin{array}{c}-0.800 * * * \\
{[0.270]}\end{array}$ & $\begin{array}{c}-0.914^{* * *} \\
{[0.284]}\end{array}$ \\
\hline $\operatorname{Exdum}_{i m t-1}$ & $\begin{array}{l}-0.003 \\
{[0.016]}\end{array}$ & $\begin{array}{l}-0.001 \\
{[0.016]}\end{array}$ & $\begin{array}{l}-0.003 \\
{[0.016]}\end{array}$ & $\begin{array}{l}-0.004 \\
{[0.016]}\end{array}$ & $\begin{array}{l}-0.001 \\
{[0.016]}\end{array}$ & $\begin{array}{l}-0.006 \\
{[0.016]}\end{array}$ & $\begin{array}{l}-0.009 \\
{[0.016]}\end{array}$ \\
\hline $\operatorname{Ln}(\mathrm{KL})_{i m t-1}$ & $\begin{array}{c}0.025^{* * *} * \\
{[0.010]}\end{array}$ & $\begin{array}{c}0.027^{* * *} \\
{[0.009]}\end{array}$ & $\begin{array}{c}0.025^{* *} \\
{[0.010]}\end{array}$ & $\begin{array}{c}0.022^{* *} \\
{[0.010]}\end{array}$ & $\begin{array}{c}0.026^{* * *} \\
{[0.010]}\end{array}$ & $\begin{array}{c}0.025^{* * *} \\
{[0.010]}\end{array}$ & $\begin{array}{c}0.029 * * * \\
{[0.010]}\end{array}$ \\
\hline $\mathrm{LabC}_{i m t-1}$ & $\begin{array}{l}-0.022 \\
{[0.065]}\end{array}$ & $\begin{array}{l}-0.022 \\
{[0.065]}\end{array}$ & $\begin{array}{l}-0.026 \\
{[0.065]}\end{array}$ & $\begin{array}{l}-0.027 \\
{[0.065]}\end{array}$ & $\begin{array}{l}-0.018 \\
{[0.065]}\end{array}$ & $\begin{array}{l}-0.032 \\
{[0.066]}\end{array}$ & $\begin{array}{l}-0.021 \\
{[0.064]} \\
\end{array}$ \\
\hline Obs & 39912 & 39912 & 39912 & 39912 & 39912 & 39912 & 39912 \\
\hline Firms & 8731 & 8731 & 8731 & 8731 & 8731 & 8731 & 8731 \\
\hline Instr. & 99 & 99 & 99 & 99 & 99 & 99 & 102 \\
\hline Hansen Test & 0.402 & 0.491 & 0.411 & 0.378 & 0.474 & 0.492 & 0.512 \\
\hline Hansen Test Lev. & 0.521 & 0.620 & 0.546 & 0.392 & 0486 & 0.525 & 0.723 \\
\hline AR2 Test & 0.2225 & 0.2344 & 0.2119 & 0.2155 & 0.2780 & 0.1888 & 0.1678 \\
\hline
\end{tabular}

$\ddagger$ System GMM estimation. Robust standard errors in squared brackets. Time dummies included both as variables and instruments. One step estimator used. Significance level: $*$ is the p-value $>0.1, * *$ is the $\mathrm{p}$-value $>0.05$, and $* * *$ is the p-value $>0.01$. Instr: total number of instruments. Lev: Hansen test for the equation in levels.

The results do not change with these specifications. The coefficients for the competition

\footnotetext{
${ }^{32}$ Energy(40), land transports(60) water transports(61), air transports(62), auxiliary transport activities(63) and telecommunication (64).
} 
proxies are still negative and significant, while in some cases (MKUP and PCM) the magnitude increases in Column (2), (5), and (7). It seems that the efficiency of the network industry (Index $(\mathrm{N}))$ is now important for TFP in manufacture (coefficient is positive and significant in Column(6)). Price $(\mathrm{N})^{33}$ coefficient is greater in Table 6 than in Table 6.1, as is the significance of the effect. The interpretations of the other coefficients does not change, with the exception of the negative and significant sign for $\mathrm{HHI}(\mathrm{M})$, which is more realistic. To conclude, the introduction of different indices does not produce any substantive changes in the previous results, even if the statistical relation is stronger.

Finally, it is performed the same exercise for the other three service groups (retail, financial services and other business activities, see Table A.1; the results are not shown, but the coefficients were not significant in any case. Therefore it is reasonable to conclude that network industries really matter for the efficiency of manufacturing firms, via the inputs used.

It is also calculated the quadratic term for the network indices; the results are shown in Table 6. The results are generally similar to those in Table 6 , with the HHI(N) coefficients being large and significant in both analyses. However FDIPW(N), unlike FDIPW(S) is highly significant in all four regressions.

To conclude this section robustness check is performed. The sample of manufacturing firms was split into two groups, one formed of large firms (L) and the other of medium-sized and medium small firms (MS). Large firms have, on average, more than 250 employees, while small firms have fewer than 250 employees. The idea is to explore whether service inputs are more important for large or small firms. The results are shown in Tables 6 and D. The first four columns show the regression results for the sub-sample of large firms, while the last four refer to the medium-small firms. The tables indicate that competition in services is more important for large firms rather than medium-sized and small ones. This may be because large enterprises use services intensively in their production. If we assume this last statement to be true, the coefficients in Tables 6 and D are clearly comprehensible.

\footnotetext{
${ }^{33} \operatorname{Price}(\mathrm{N})$ is constructed as a weighted mean of output deflators for all networks, using as weights the I-O coefficients. Price(S) is directly derived by EU-KLEMS.
} 
Table 6.4: Network Services - Quadratic Term ${ }^{\ddagger}$.

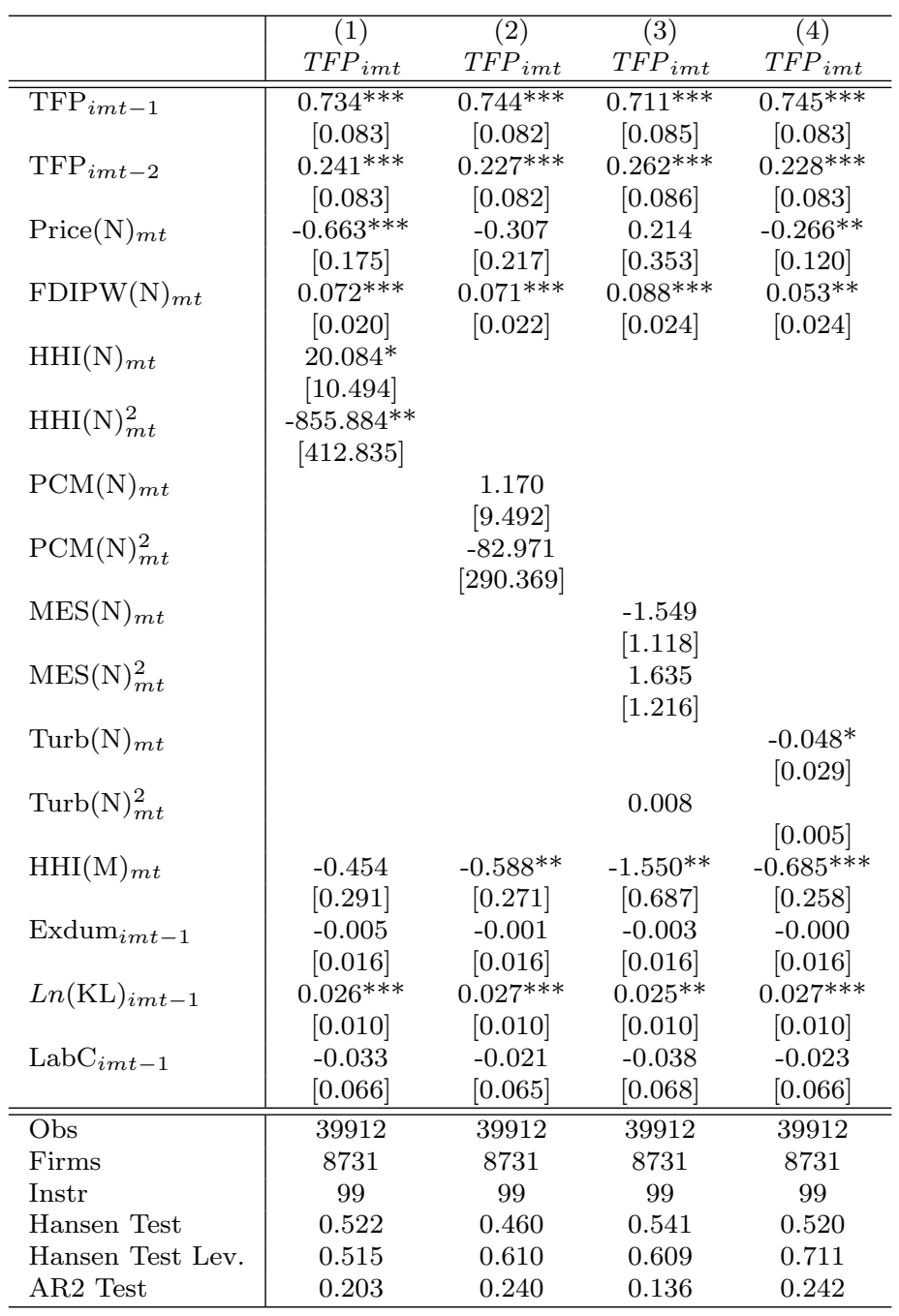

$\ddagger$ System GMM estimation. Robust standard errors in squared brackets. Time dummies included both as variables and instruments. One step estimator used. Significance level: $*$ is the p-value $>0.1, * *$ is the $\mathrm{p}$-value $>0.05$, and $* * *$ is the $\mathrm{p}$-value $>0.01$. Instr: total number of instruments. Lev: Hansen test for the equation in levels. 


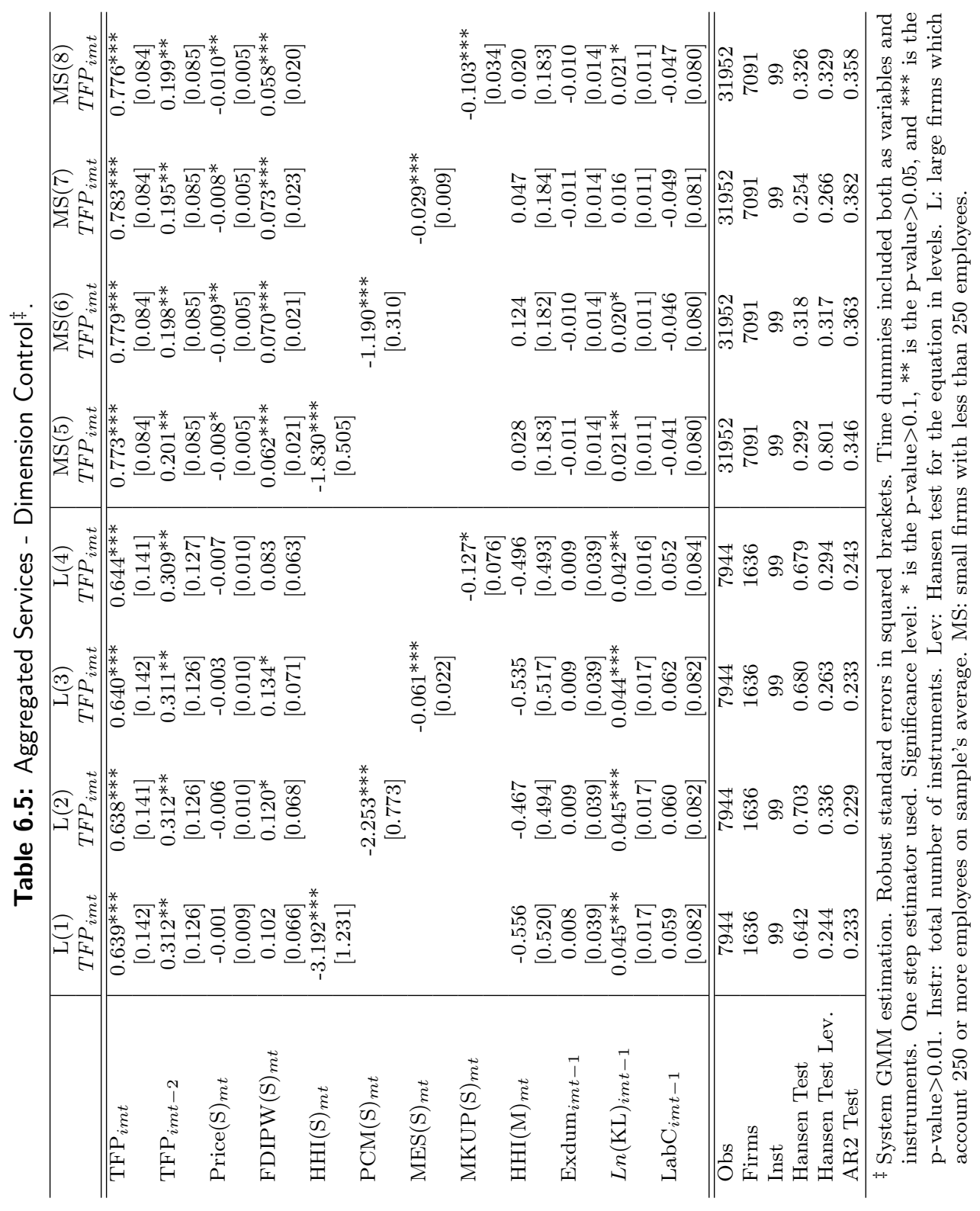


The aim of the section was to explore empirically whether competition in services matters for the productivity of manufacturing firms because of the contribution services make to their inputs. To sum up, it is now possible to state that competition and the market structure or service industries have a significant and non-negligible effect on the productivity of manufacturing industries. Network services may well be the cause of this relationship, because of the importance of their input (communication, energy and transport) Secondly, the effect of competition on downstream efficiency is not linear: insisting on perfect competition in services is not the best way to foster the efficiency downstream. There are economies of scale that have to be exploited, as well as investments to recover. Unfortunately it is not possible to infer the average level of competition for each industry from the coefficients $\beta_{1}$; the index in Equation (4.9) is a weighted average of a specific term across service industries. Information about firms' individual consumption of services would be extremely useful for exploring these issues further.

\section{Conclusions}

This paper has tried to assess the importance of the market structure of the service sector for manufacturing firms. On one hand, services comprise an increasing proportion of the inputs used by manufacturing firms, and so concerns about services are rising. On the other hand, competition in the service market is completely different from competition in traditional sectors for historical and technical reasons. Services operate in a highly regulated and protected market, while manufacturing firms are exposed to global competition. This kind of asymmetry could create problems, for firms' competitiveness: manufacturing performances can be significantly affected. This concern is not negligible in particular for firms' productivity and large firms. The paper suggests that this kind of relation is driven by the competition in network service industries.

However if competition is pushed further, the benefits for manufacturing firms decrease: the existence of investments and economies to scale that have to be exploited, requires a certain threshold of "protection" to ensure that high quality services are provided.

The empirical results suggest a bunch of preliminary policy conclusions. Some of the inefficiencies in upstream sectors are caused by over-regulation and entry barriers that reduce the positive effect of competition, and pro-competitive policies in the tertiary sector should translate into better services for manufacturing firms. However it is important to stress that services are highly heterogenous among them, and policy makers have to be aware about different interventions. In particular network service industries have three main characteristics making them different from manufacturing: they are of strategic interest for a national economy, there are natural entry barriers to many of them (i.e. it is too costly to duplicate a network); and they do not face international competition from exports. Therefore in the light of previous results, there may be four reasonable arguments against deregulation and liberalization: a) a fear that the public service ethic will be compromised, b) a concern that employees will lose their social benefits; c) worries about whether the regulated industries can promote innovation and industrial development; and d) the perceived risk of "market failure" in a competitive environment.

To conclude, further analysis is required for more accurate results, with particular attention to the different types of services that manufacturing uses. In particular it seems fruitful to test if competition in services affect the international competition of manufacturing firms, i.e. their ability to enter in the export market. However more detailed dataset containing information about service consumption at firm level or at higher level of disaggregation should be used for this work . 


\section{References}

[1] Altomonte C., Barattieri A.(2005). Endogenous Mark-up, International Trade, and Output Mix, mimeo

[2] Amiti M, Konings J (2007):Trade liberalization, intermediate inputs and productivity: evidence from Indonesia, American Economic Review, vol. 97(5)

[3] ArellanoM. Bond S.R. (1991): Some specification test for panel data: Monte Carlo evidence and an application to employment equations, Review of Economic Studies, 58 277-298

[4] Arnold M. Javorcik B. and Mattoo A. (2006): The Productivity Effects of Services Liberalization: Evidence from the Czech Republic, CEPR Working Paper

[5] Aw B., Geeta B., Roberts M.J.(2001) Firm Heterogeneity and Export-domestic Price Differentials: A Study of Taiwanese Electronics Products, Journal of International Economics, Vol. 54(1), pp 149-169

[6] Barba-Navaretti G., Faini R., Haskel J., Scarpa C., Wey C. (2006): Contrasting Europe's decline: do product market reforms help? in T. Boeri, M. Castanheira and R. Faini (eds) Structural reforms without apologies, Oxford University Press, in press.

[7] Bernard A.B. Jensen B.J. (1999): Exceptional Exporter Performance: Cause, Effect or Both? Journal of International Economics, Vol. 47 (1), pp. 1-25.

[8] Bernard A, Redding S, Schott P.K. (2004): Comparative advantage and heterogeneous firms NBER WP 10668

[9] Blundell R., Bond B. (1998): Initial conditions and moment restrictions in dynamic panel model, Journal of Econometrics vol.87, pp.115-143

[10] Bolkestein directive: European directive n 2006/0001,

[11] Clerides S. Lach S. Tybout J.(1998): Is 'Learning-by-Exporting' Important? Micro-Dynamic Evidence from Colombia, Mexico, and Morocco, Quarterly Journal of Economics, Vol. 113, pp. 903-47.

[12] De Leocker I. (2007): Do Exports Generate Higher Productivity? Evidence from Slovenia, Journal of International Economics, Vol.73, pp.6998

[13] Daveri F., Silva O. (2004): Not only Nokia: what Finland tells us about "new economy" growth, Economic Policy, vol 19(38) pp345-362

[14] Fernandes A.M., Paunov C. (2008): Services FDI and manufactruing productivity growth: there is a link, Policy Research Working Paper Series 4730, The World Bank

[15] Fugazza M., Robert-Nicoud F.(2005) Can South-South trade liberalization stimulate NorthSouth trade? CEPR Discussion Papers 5699

[16] Gabszewicz J., Zanaj S. (2007): Competition in successive markets: entry and mergers CORE Discussion Paper 2006/97

[17] Gordon(2004): Five Puzzles in the Behavior of Productivity, Investment, and Innovation CEPR Discussion Paper 4414 
[18] Gorodnichenko Y. Svenjar J. Terrel K. (2007): When does FDI have positive spillover? Evidence from 17 emerging economies, mimeo

[19] Grossman G.M., Helpman H. (1991): Innovation and Growth in the Global Economy, ed. MIT Press

[20] Helpman H., Melitz M., Yeaple S., (2004): Export versus FDI with Heterogenous Firms, American Economic Review vol 94 (1) 300-317

[21] Kasahara, Lapham B. (2009): Productivity and the Decision to Import and Export: Theory and Evidence, Journal of International Economics, forthcoming

[22] Klette T.J., Griliches Z. (1996): The Inconsistency of Common Scale Estimators when Output Prices are Unobserved and Endogneous, Journal of Apllied Econometrics, vol.11(4), pp. 343-361

[23] Konings J., Vandenbussche H. (2005): Antidumping Protection and Markups of Domestic Firms: Evidence from firm level data, Journal of International Economics, 65, pp. 151-165

[24] Konings J., Vandenbussche H. (2008): Heterogeneous Responses to Trade Protection, Journal of International Economics, forthcoming

[25] Lipsey (2006) Measuring international trade in services NBER working paper 12271

[26] Maioli S., Ferret B., Girma S., Gorg H. (2005): FDI, Trade, and Plant-Level Price-Cost Margins in the UK, GEP Leverhulme Mimeo

[27] OECD Council at ministerial level (2005): Growth in services: Fostering employment productivity and innovation.

[28] Pavcnik N. (2002): Trade Liberalization, Exit, and Productivity Improvements: Evidence from Chilean Plants. Review of Economic Studies 69

[29] Pisani-Ferry J. (2006):" Du bon usage de la directive services

[30] Olley S., and Pakes A. (1996): The Dynamics of Productivity in the Telecommunications Equipment Industry, Econometrica, Vol 64 (6), pp. 1263-98

[31] Roeger W. (1995): "Can Imperfect competition explain the difference between primal and dual productivity measure? Estimates from US manufacturing" Journal of Political economy, 103

[32] Roodman D. (2006): How to do xtabond2: an introduction to "Difference" and "System" GMM in Stata, Working paper 103, Center for Global Development,Washington

[33] Tybout J. (2003): Plant and Firm level evidence on "New Trade theories", Handbooks of international economics, ed by Harrigan J. Choi K.

[34] Vandenbussche H., Veugelers R. (1999): European Antidumping Policy and the Profitability of National versus International Collusion, European Economic Review, January, 47 (1)

[35] Woolridge J.(2002): Econometric Analysis of Cross Sections and Panel Data, Cambridge, The MIT Pres. 


\section{A Data Description}

Table A.1: Sectors-Manufactures and Services

\begin{tabular}{|c|c|c|}
\hline Nace 2 digit Code & Manufacturing sectors & \\
\hline 15 & Food & \\
\hline 17 & Textile & \\
\hline 18 & Wearing Apparel & \\
\hline 19 & Leather & \\
\hline 22 & Publishing & \\
\hline 24 & Manufacture of chemicals and chemical products & \\
\hline 25 & Manufacture of rubber and plastic products & \\
\hline 26 & Manufacture of other non-metallic mineral products & \\
\hline 27 & Manufacture of basic metals & \\
\hline 28 & Manufacture of fabricated metal products & \\
\hline 29 & Manufacture of machinery and equipment & \\
\hline 30 & Manufacture of office machinery and computers & \\
\hline 31 & Manufacture of electrical machinery & \\
\hline 32 & Manufacture of radio, television, communication equipment & \\
\hline 33 & Manufacture of medical, precision and optical instruments & \\
\hline 34 & Manufacture of motor vehicle & \\
\hline 35 & Manufacture of other transport equipment & \\
\hline 36 & Other Manufactures n.e.c. & \\
\hline \multicolumn{3}{|c|}{ Services } \\
\hline 40 & Energy & Network Services \\
\hline 50 & Wholesale and Retail & Retail \\
\hline 60 & Land Transport & Network Services \\
\hline 61 & Water Transport & Network Services \\
\hline 62 & Air Transport & Network Services \\
\hline 63 & Auxiliary transport services & Network Services \\
\hline 64 & Telecommunication and posts & Network Services \\
\hline 65 & Financial Intermediation & Financial Service \\
\hline 70 & Real estate activities & Other Business \\
\hline 72 & Computer and Related activities & Other Business \\
\hline 73 & R\&D & Other Business \\
\hline 74 & Other Business activities & Other Business \\
\hline
\end{tabular}

Table A.2: FDI flows in France ${ }^{\ddagger}$.

\begin{tabular}{c|c|c|c|c|c|c|c}
\hline 1996 & 1997 & 1998 & 1999 & 2000 & 2001 & 2002 & 2003 \\
\hline \multicolumn{7}{c}{ FDI FLOWS (Millions of Euros) } \\
\hline \hline 17128 & 20619 & 27866 & 43688 & 46945 & 56407 & 51695 & 41627 \\
\hline \multicolumn{7}{c}{ FDI FLOWS in Manufacturing (Millions of Euros) } \\
\hline \hline 3897 & 4542 & 7071 & 8131 & 14897 & 11906 & 20036 & 8793 \\
\hline \hline 14061 & 15589 & 18851 & 33675 & 29471 & 47313 & 36650 & 32532 \\
\hline \multicolumn{7}{c}{ Percentage of Service FDI on Total FDI } \\
\hline \hline 0.82 & 0.75 & 0.68 & 0.77 & 0.63 & 0.84 & 0.71 & 0.78 \\
\hline$\ddagger$ Source: OECD
\end{tabular}


Table A.3: Production function estimation Olley \& Pakes ${ }^{\ddagger}$.

\begin{tabular}{l|cccccc}
\hline Sector & Labor & SE $(\mathrm{l})$ & Material & $\mathrm{SE}(\mathrm{m})$ & Capital & $\mathrm{SE}(\mathrm{k})$ \\
\hline \hline 15 & 0.252 & 0.010 & 0.542 & 0.013 & 0.017 & 0.010 \\
17 & 0.213 & 0.015 & 0.446 & 0.031 & -0.031 & 0.031 \\
18 & 0.069 & 0.023 & 0.376 & 0.062 & 0.071 & 0.039 \\
19 & 0.198 & 0.027 & 0.511 & 0.027 & 0.056 & 0.066 \\
22 & 0.343 & 0.026 & 0.196 & 0.011 & 0.064 & 0.017 \\
24 & 0.275 & 0.017 & 0.459 & 0.016 & 0.068 & 0.018 \\
25 & 0.351 & 0.014 & 0.495 & 0.023 & 0.076 & 0.028 \\
26 & 0.275 & 0.011 & 0.467 & 0.023 & 0.040 & 0.015 \\
27 & 0.186 & 0.020 & 0.563 & 0.013 & 0.070 & 0.046 \\
28 & 0.471 & 0.012 & 0.236 & 0.010 & 0.024 & 0.015 \\
29 & 0.497 & 0.025 & 0.287 & 0.018 & 0.046 & 0.030 \\
30 & 0.647 & 0.060 & 0.419 & 0.031 & 0.047 & 0.101 \\
31 & 0.415 & 0.032 & 0.402 & 0.021 & 0.009 & 0.017 \\
32 & 0.368 & 0.036 & 0.437 & 0.038 & 0.075 & 0.044 \\
33 & 0.453 & 0.022 & 0.289 & 0.020 & 0.143 & 0.047 \\
34 & 0.328 & 0.026 & 0.514 & 0.043 & 0.044 & 0.053 \\
35 & 0.495 & 0.031 & 0.207 & 0.021 & 0.141 & 0.071 \\
36 & 0.401 & 0.011 & 0.473 & 0.017 & 0.059 & 0.026 \\
\hline \hline
\end{tabular}

¥ Source: Amadeus Dataset Standard errors boostrapped over 100 replications. Time dummies included.

\section{B Competition in Services}

Table B.1: Services sector competition index: year-sector ${ }^{\ddagger}$.

\begin{tabular}{l|ccccccccc}
\hline Index-Sector & 1996 & 1997 & 1998 & 1999 & 2000 & 2001 & 2002 & 2003 & 2004 \\
\hline \hline HHI-40 & 0.2002 & 0.1873 & 0.3401 & 0.1815 & 0.1833 & 0.2334 & 0.2372 & 0.2754 & 0.4168 \\
HHI-64 & 0.8440 & 0.8137 & 0.8186 & 0.8074 & 0.5448 & 0.4447 & 0.4380 & 0.3380 & 0.4269 \\
HHI-74 & 0.0810 & 0.0796 & 0.0754 & 0.0689 & 0.0652 & 0.0649 & 0.0605 & 0.0549 & 0.0471 \\
\hline Index-40 & -0.1386 & -0.1478 & -0.1314 & 0.0149 & -0.0208 & -0.1367 & -0.0206 & 0.1420 & -0.0589 \\
Index-64 & 0.4776 & 0.2013 & 0.5005 & 0.9121 & 1.0419 & 1.2418 & 0.8465 & 1.1290 & 0.9204 \\
Index-74 & -0.1598 & 0.0525 & 0.1644 & 0.3787 & 0.4816 & 0.4764 & 0.5047 & 0.5464 & 0.3985 \\
\hline PCM-40 & 0.6763 & 0.6534 & 0.6646 & 0.6340 & 0.6396 & 0.5557 & 0.6176 & 0.6386 & 0.6021 \\
PCM-64 & 0.6993 & 0.6875 & 0.7041 & 0.6998 & 0.6625 & 0.6699 & 0.7062 & 0.6778 & 0.7434 \\
PCM-74 & 0.4334 & 0.4066 & 0.4199 & 0.4308 & 0.4015 & 0.3847 & 0.3873 & 0.3951 & 0.3792 \\
\hline
\end{tabular}

¥ Source: Calculation from Amadeus dataset. TFP calculated according to equation 4.8. 
Figure 1: Competition in Services.

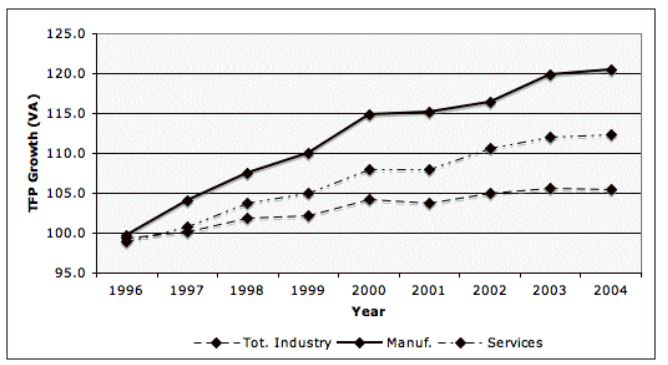

(a) TFP Growth value added based for France (base year 1995 , TFP=100).

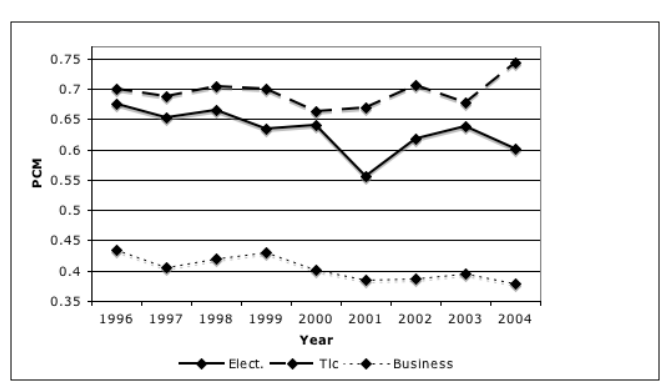

(c) Average Price Cost Margin

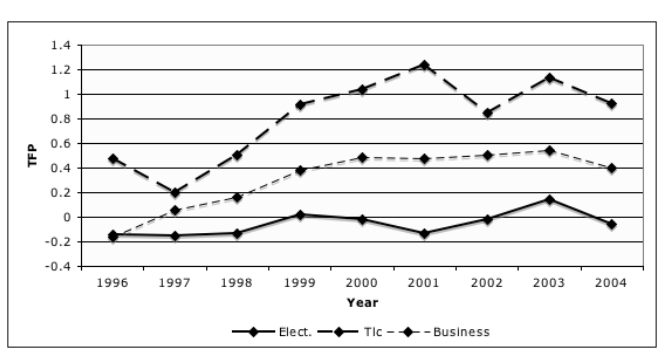

(b) Average Sector Productivity: Efficiency Index.

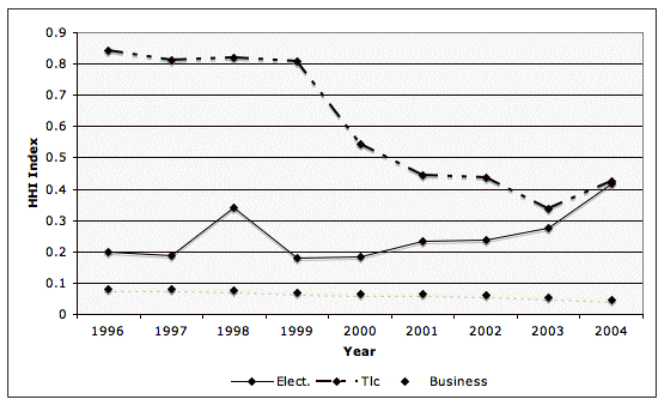

(d) Herfindahl Index

Table B.2: Average Competition Indeces ${ }^{\ddagger}$.

\begin{tabular}{c|ccccc}
\hline Sector & HHI & PCM & MES & MKUP & Index \\
\hline \hline 40 & 0.251 & 0.630 & 10.876 & 0.906 & -0.059 \\
50 & 0.108 & 0.196 & 9.179 & 1.261 & 0.357 \\
60 & 0.051 & 0.563 & 9.688 & 3.768 & 0.306 \\
61 & 0.230 & 0.786 & 10.480 & 9.724 & 0.477 \\
62 & 0.345 & 0.693 & 10.847 & 3.772 & 0.475 \\
63 & 0.086 & 0.700 & 9.908 & 1.890 & 0.263 \\
64 & 0.608 & 0.696 & 11.968 & 4.802 & 0.920 \\
65 & 0.219 & 0.387 & 10.670 & 1.463 & 1.206 \\
70 & 0.097 & 0.664 & 10.395 & 1.131 & -0.152 \\
71 & 0.158 & 0.659 & 10.622 & 1.854 & 0.390 \\
72 & 0.081 & 0.456 & 10.489 & 1.982 & 0.728 \\
73 & 0.120 & 0.497 & 10.433 & 1.952 & 0.047 \\
74 & 0.066 & 0.397 & 11.089 & 1.115 & 0.398 \\
\hline \hline
\end{tabular}

¥ Source: Amadeus Dataset

\section{Mark-up estimation.}

One method to estimate markup is suggested and demonstrated by Roeger (1995). The procedure is very useful for micro level data but it allow us only to estimate average markup (as parameter) and not year variant index. This methodology accounts problems of endogeneity and simultaneity of investment on productivity shocks for the estimation of markups at firm level. 
Table B.3: Number of firms in services: year sector ${ }^{\ddagger}$.

\begin{tabular}{c|ccccccccc}
\hline Sector & 1996 & 1997 & 1998 & 1999 & 2000 & 2001 & 2002 & 2003 & 2004 \\
\hline \hline 40 & 45 & 46 & 51 & 53 & 61 & 66 & 71 & 70 & 75 \\
50 & 2690 & 2765 & 2867 & 2978 & 3168 & 3296 & 3482 & 3543 & 3821 \\
60 & 191 & 192 & 200 & 205 & 215 & 216 & 223 & 231 & 249 \\
61 & 16 & 17 & 17 & 19 & 22 & 22 & 24 & 24 & 27 \\
62 & 12 & 13 & 15 & 16 & 15 & 15 & 18 & 19 & 21 \\
63 & 259 & 268 & 283 & 289 & 300 & 307 & 316 & 330 & 342 \\
64 & 20 & 24 & 30 & 36 & 47 & 53 & 52 & 59 & 61 \\
65 & 78 & 87 & 106 & 119 & 183 & 219 & 254 & 279 & 344 \\
70 & 312 & 326 & 364 & 365 & 405 & 433 & 456 & 487 & 524 \\
71 & 93 & 95 & 101 & 98 & 107 & 113 & 119 & 132 & 141 \\
72 & 154 & 167 & 183 & 203 & 227 & 244 & 250 & 256 & 266 \\
73 & 31 & 33 & 35 & 35 & 38 & 39 & 42 & 43 & 46 \\
74 & 744 & 772 & 865 & 928 & 1238 & 1418 & 1591 & 1783 & 2039 \\
\hline \hline Total & 4645 & 4805 & 5117 & 5344 & 6026 & 6441 & 6898 & 7256 & 7956 \\
\hline
\end{tabular}

$\ddagger$ Source: Amadeus Dataset

Giving a short summarize of the procedure we can understand better the benefit in applying it: for a more detailed analysis I advice to refer to Roeger $(1995)^{2}$.

Starting to consider a linear homogeneous production function with three inputs, so firm $i$ in period $t$ will have as production function

$$
Y_{i t}=A_{i t} G\left(L_{i t}, K_{i t}, M_{i t}\right)
$$

where $Y$ is the production while $L, K, M$ are respectively inputs of labor, capital and other intermediates and $A_{i t}$ represents variation in efficiency for $i$ at time $t$. Under imperfect competition, the Solow residual can be written as

$$
\begin{aligned}
S R_{i t} & =\left(\Delta Y_{i t}-\Delta K_{i t}\right)-\alpha_{L i t}\left(\Delta L_{i t}-\Delta K_{i t}\right)-\alpha_{M i t}\left(\Delta M_{i t}-\Delta K_{i t}\right) \\
& =B_{i t}\left(\Delta Y_{i t}-\Delta K_{i t}\right)+\left(1-B_{i t}\right) \Delta A_{i t}
\end{aligned}
$$

where $\Delta X_{i t}$ is the $\log$ difference of variable $X_{i t}$ and $\alpha_{J i t}=P_{J i t} J_{i t} / P_{i t} Y_{i t}$ are shares of $j$-th input on total sales. The SR could be divided in two different components: imperfect competition term $\left(B_{i t}\left(\Delta Y_{i t}-\Delta K_{i t}\right)\right)$ and technology growth term $\left(\Delta A_{i t}\right)$. Then market power of $i$-th at time $t$ firm is measured by $B_{i t}=\left(P_{i t}-c_{i t}\right) / P_{i t}=1-1 / \mu_{i t}$ where $c_{i t}$ is firm marginal cost, $P_{i t}$ is the good price and $\mu_{i t}$ is the price cost mark-up. Shares and factor input are observable but it is necessary to estimate markups and productivity shocks: it could be difficult estimate $B_{i t}$ (and markups), given that $\left(\Delta Y_{i t}-\Delta K_{i t}\right)$ and $\Delta A_{i t}$ are correlated. We can just imagine technology shock composed by two parts (as Olley and Pakes 1996)

$$
A_{i t}=\xi_{i t}+\omega_{i t}
$$

Firms productivity is composed by unexpected shocks due to external factors ( $\omega_{i t}$ as white noise) and an expected components $\left(\xi_{i t}\right)$ due to conscious investment choices: clearly both are

\footnotetext{
${ }^{2}$ The paper was written to give an ansewer to TFP measurement problems, as simultaneity bias. He argued that Solow residual measurement errors are caused by endogenity of productivity shocks with capital stock. Markup is due to the fact that we are in a framework of imperfect competition
} 
unobserved by econometricians. The expected $\xi$ could be correlated with inputs levels so OLS suffer of simultaneity: find right instruments could be an hard task. Roeger derives a dual Solow residual, price based, where $w_{i t}, r_{i t}$ and $z_{i t}$ are respectively the labor wage $\left(L_{i t}\right)$, capital rental $\operatorname{price}\left(K_{i t}\right)$ and intermediate inputs $\operatorname{cost}\left(M_{i t}\right)$ for firm $i$ at time $t$,

$$
D S R_{i t}=\alpha_{L i t} \Delta w_{i t}+\alpha_{M i t} \Delta z_{i t}+\left(1-\alpha_{L i t}-\alpha_{M i t}\right) \Delta r_{i t}
$$

If we subtract (C.4) from $(C .2)$ we get net Solow residual

$$
\begin{aligned}
S R_{i t}-D S R_{i t}= & \left(\Delta Y_{i t}+\Delta P_{i t}\right)-\alpha_{L i t}\left(\Delta L+\Delta w_{i t}\right)- \\
& \alpha_{M i t}\left(\Delta M_{i t}+\Delta z_{i t}\right) \\
& -\left(1-\alpha_{L i t}-\alpha_{M i t}\right)\left(\Delta K_{i t}+\Delta r_{i t}\right) \\
= & B_{i t}\left[\left(\Delta Y_{i t}+\Delta P_{i t}\right)-\left(\Delta K_{i t}+\Delta r_{i t}\right)\right]
\end{aligned}
$$

where term $\left(1-B_{i t}\right) \Delta A_{i t}$ which is source of endogeneity, does not appear. Now equation $(C .2)$ could be evaluated without using instrumental variables. Rearranging $(C .5)$ we can write

$$
\begin{array}{ll} 
& \left(\Delta Y_{i t}+\Delta P_{i t}\right)-\left(\Delta K_{i t}+\Delta r_{i t}\right) \\
= & \mu_{i t}\left\{\alpha_{L i t}\left[\left(\Delta L_{i t}+\Delta w_{i t}\right)-\left(\Delta K_{i t}+\Delta r_{i t}\right)\right]\right. \\
& \left.+\alpha_{M i t}\left[\left(\Delta M_{i t}+\Delta z_{i t}\right)-\left(\Delta K_{i t}+\Delta r_{i t}\right)\right]\right\} .
\end{array}
$$

Considering that $\Delta X_{i t}$ are log differences, we can estimate it quite easily: the parenthesis terms are nominal growth rate so the right hand side is output growth minus capital growth, while left hand side is a weighted average of intermediate and labor input growth rate. We have data on a period of 10 years but that's not enough to calculate markup of each firm separately, so it is possible to measure average markup $\mu_{i t}$ as parameter of composite variable $\Delta x_{i t}$ (right hand side of C.6)

$$
\Delta Q_{i t}=\alpha_{i}+\mu_{1} \Delta x_{i t}+v_{i t}
$$

where $\mu_{1}$ is the markup, term $\alpha_{i}$ is firm specific heterogeneity and $v_{i t}$ is white noise error term. The coefficients are estimated with a fixed effect estimator 


\section{Additional Tables}

Table D.1: Network Services - OLS Baseline Equation ${ }^{\ddagger}$.

\begin{tabular}{|c|c|c|c|c|c|c|c|}
\hline & $\begin{array}{c}(1) \\
T F P_{i m t} \\
\end{array}$ & $\begin{array}{c}(2) \\
T F P_{i m t} \\
\end{array}$ & $\begin{array}{c}(3) \\
T F P_{i m t} \\
\end{array}$ & $\begin{array}{c}(4) \\
T F P_{i m t} \\
\end{array}$ & $\begin{array}{c}(5) \\
T F P_{i m t} \\
\end{array}$ & $\begin{array}{c}(6) \\
T F P_{i m t} \\
\end{array}$ & $\begin{array}{c}(7) \\
T F P_{i m t} \\
\end{array}$ \\
\hline $\operatorname{Price}(\mathrm{N})_{m t}$ & $\begin{array}{c}-2.698^{* * *} \\
{[0.115]}\end{array}$ & $\begin{array}{c}-2.121^{* * *} \\
{[0.141]}\end{array}$ & $\begin{array}{c}-2.624^{* * *} \\
{[0.138]}\end{array}$ & $\begin{array}{c}-3.341^{* * *} \\
{[0.119]}\end{array}$ & $\begin{array}{c}-3.774^{* * *} \\
{[0.140]}\end{array}$ & $\begin{array}{c}-5.485 * * * \\
{[0.106]}\end{array}$ & $\begin{array}{c}-5.040 * * * \\
{[0.204]}\end{array}$ \\
\hline $\operatorname{FDIPW}(\mathrm{N})_{m t}$ & $\begin{array}{c}1.931^{* * * *} \\
{[0.067]}\end{array}$ & $\begin{array}{c}1.906 * * * \\
{[0.067]}\end{array}$ & $\begin{array}{c}1.927^{* * *} * \\
{[0.067]}\end{array}$ & $\begin{array}{c}1.930 * * * \\
{[0.068]}\end{array}$ & $\begin{array}{c}1.828^{* * *} * \\
{[0.070]}\end{array}$ & $\begin{array}{c}2.346^{* * *} \\
{[0.060]}\end{array}$ & $\begin{array}{c}2.611^{* * * *} \\
{[0.056]}\end{array}$ \\
\hline $\mathrm{HHI}(\mathrm{N})_{m t}$ & $\begin{array}{c}-3.681^{* * * *} \\
{[0.674]}\end{array}$ & & & & & & $\begin{array}{c}-46.085^{* * *} \\
{[2.095]}\end{array}$ \\
\hline $\mathrm{PCM}(\mathrm{N})_{m t}$ & & $\begin{array}{c}-8.395^{* * *} \\
{[0.881]}\end{array}$ & & & & & $\begin{array}{c}26.543^{* * *} \\
{[2.364]}\end{array}$ \\
\hline $\operatorname{MES}(\mathrm{N})_{m t}$ & & & $\begin{array}{c}-0.068^{* *} \\
{[0.028]}\end{array}$ & & & & $\begin{array}{c}-1.027 * * * \\
{[0.107]}\end{array}$ \\
\hline $\operatorname{MKUP}(\mathrm{N})_{m t}$ & & & & $\begin{array}{c}1.286^{* * *} \\
{[0.083]}\end{array}$ & & & \\
\hline $\operatorname{TURB}(\mathrm{N})_{m t}$ & & & & & $\begin{array}{c}0.121^{* * *} \\
{[0.009]}\end{array}$ & & \\
\hline $\operatorname{INDEX}(\mathrm{N})_{m t}$ & & & & & & $\begin{array}{c}52.917^{* * *} \\
{[0.900]}\end{array}$ & $\begin{array}{c}81.510^{* * *} \\
{[1.037]}\end{array}$ \\
\hline $\mathrm{HHI}(\mathrm{M})_{m t}$ & $\begin{array}{c}-18.142^{* * *} \\
{[0.250]}\end{array}$ & $\begin{array}{c}-18.048^{* * *} \\
{[0.246]}\end{array}$ & $\begin{array}{c}-18.030^{* * *} \\
{[0.247]}\end{array}$ & $\begin{array}{c}-17.828^{* * *} \\
{[0.243]}\end{array}$ & $\begin{array}{c}-18.176^{* * *} \\
{[0.246]}\end{array}$ & $\begin{array}{c}-17.760^{* * *} \\
{[0.240]}\end{array}$ & $\begin{array}{c}-19.357^{* * *} \\
{[0.251]}\end{array}$ \\
\hline $\operatorname{Exdum}_{i m t-1}$ & $\begin{array}{c}0.049 * * * \\
{[0.008]}\end{array}$ & $\begin{array}{c}0.051 * * * \\
{[0.008]}\end{array}$ & $\begin{array}{c}0.048^{* * *} \\
{[0.008]}\end{array}$ & $\begin{array}{c}0.040^{* * *} \\
{[0.008]}\end{array}$ & $\begin{array}{c}0.042^{* * *} * \\
{[0.008]}\end{array}$ & $\begin{array}{c}0.025 * * * \\
{[0.008]}\end{array}$ & $\begin{array}{c}0.048^{* * * *} \\
{[0.008]}\end{array}$ \\
\hline $\operatorname{Ln}(\mathrm{KL})_{i m t-1}$ & $\begin{array}{c}0.131^{* * *} \\
{[0.004]}\end{array}$ & $\begin{array}{c}0.132^{* * *} \\
{[0.004]}\end{array}$ & $\begin{array}{c}0.129 * * * \\
{[0.004]}\end{array}$ & $\begin{array}{c}0.119 * * * \\
{[0.004]}\end{array}$ & $\begin{array}{c}0.124^{* * * *} \\
{[0.004]}\end{array}$ & $\begin{array}{c}0.098^{* * * *} \\
{[0.004]}\end{array}$ & $\begin{array}{c}0.127^{* * * *} \\
{[0.004]}\end{array}$ \\
\hline $\mathrm{LabC}_{i m t-1}$ & $\begin{array}{c}1.505^{* * * *} \\
{[0.021]}\end{array}$ & $\begin{array}{c}1.508^{* * *} \\
{[0.021]}\end{array}$ & $\begin{array}{c}1.505^{* * *} \\
{[0.021]}\end{array}$ & $\begin{array}{c}1.489 * * * \\
{[0.021]}\end{array}$ & $\begin{array}{c}1.490^{* * *} * \\
{[0.021]}\end{array}$ & $\begin{array}{c}1.300^{* * *} \\
{[0.020]}\end{array}$ & $\begin{array}{c}1.212^{* * * *} \\
{[0.020]}\end{array}$ \\
\hline $\begin{array}{l}\text { Obs } \\
R^{2}\end{array}$ & $\begin{array}{l}51692 \\
0.179\end{array}$ & $\begin{array}{l}51692 \\
0.179\end{array}$ & $\begin{array}{l}51692 \\
0.178\end{array}$ & $\begin{array}{l}51689 \\
0.182\end{array}$ & $\begin{array}{l}51692 \\
0.181\end{array}$ & $\begin{array}{l}51692 \\
0.244\end{array}$ & $\begin{array}{l}51692 \\
0.280\end{array}$ \\
\hline
\end{tabular}

‡ Ordinary Least Sqaure. Robust standard error, clusterd by sector, are in squared brackets. Time dummies included. 


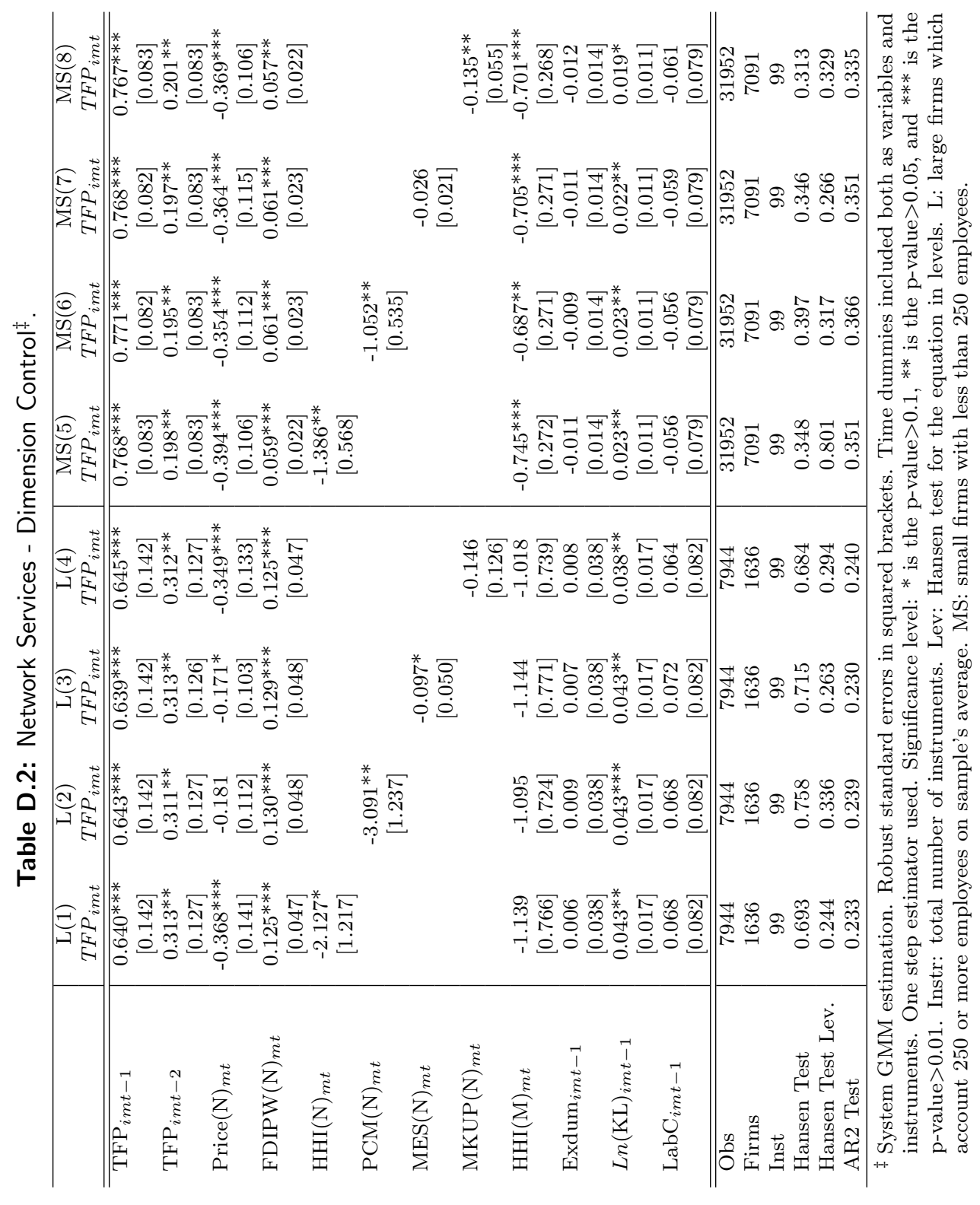




\section{CESifo Working Paper Series}

for full list see www.cesifo-group.org/wp

(address: Poschingerstr. 5, 81679 Munich, Germany, office@cesifo.de)

2881 Marko Koethenbuerger and Michael Stimmelmayr, Corporate Taxation and Corporate Governance, December 2009

2882 Gebhard Kirchgässner, The Lost Popularity Function: Are Unemployment and Inflation no longer Relevant for the Behaviour of Germany Voters?, December 2009

2883 Marianna Belloc and Ugo Pagano, Politics-Business Interaction Paths, December 2009

2884 Wolfgang Buchholz, Richard Cornes and Dirk Rübbelke, Existence and Warr Neutrality for Matching Equilibria in a Public Good Economy: An Aggregative Game Approach, December 2009

2885 Charles A.E. Goodhart, Carolina Osorio and Dimitrios P. Tsomocos, Analysis of Monetary Policy and Financial Stability: A New Paradigm, December 2009

2886 Thomas Aronsson and Erkki Koskela, Outsourcing, Public Input Provision and Policy Cooperation, December 2009

2887 Andreas Ortmann, "The Way in which an Experiment is Conducted is Unbelievably Important": On the Experimentation Practices of Economists and Psychologists, December 2009

2888 Andreas Irmen, Population Aging and the Direction of Technical Change, December 2009

2889 Wolf-Heimo Grieben and Fuat Şener, Labor Unions, Globalization, and Mercantilism, December 2009

2890 Conny Wunsch, Optimal Use of Labor Market Policies: The Role of Job Search Assistance, December 2009

2891 Claudia Buch, Cathérine Tahmee Koch and Michael Kötter, Margins of International Banking: Is there a Productivity Pecking Order in Banking, too?, December 2009

2892 Shafik Hebous and Alfons J. Weichenrieder, Debt Financing and Sharp Currency Depreciations: Wholly vs. Partially Owned Multinational Affiliates, December 2009

2893 Johannes Binswanger and Daniel Schunk, What is an Adequate Standard of Living during Retirement?, December 2009

2894 Armin Falk and James J. Heckman, Lab Experiments are a Major Source of Knowledge in the Social Sciences, December 2009

2895 Hartmut Egger and Daniel Etzel, The Impact of Trade on Employment, Welfare, and Income Distribution in Unionized General Oligopolistic Equilibrium, December 2009 
2896 Julian Rauchdobler, Rupert Sausgruber and Jean-Robert Tyran, Voting on Thresholds for Public Goods: Experimental Evidence, December 2009

2897 Michael McBride and Stergios Skaperdas, Conflict, Settlement, and the Shadow of the Future, December 2009

2898 Ben J. Heijdra and Laurie S. M. Reijnders, Economic Growth and Longevity Risk with Adverse Selection, December 2009

2899 Johannes Becker, Taxation of Foreign Profits with Heterogeneous Multinational Firms, December 2009

2900 Douglas Gale and Piero Gottardi, Illiquidity and Under-Valuation of Firms, December 2009

2901 Donatella Gatti, Christophe Rault and Anne-Gaël Vaubourg, Unemployment and Finance: How do Financial and Labour Market Factors Interact?, December 2009

2902 Arno Riedl, Behavioral and Experimental Economics Can Inform Public Policy: Some Thoughts, December 2009

2903 Wilhelm K. Kohler and Marcel Smolka, Global Sourcing Decisions and Firm Productivity: Evidence from Spain, December 2009

2904 Marcel Gérard and Fernando M. M. Ruiz, Corporate Taxation and the Impact of Governance, Political and Economic Factors, December 2009

2905 Mikael Priks, The Effect of Surveillance Cameras on Crime: Evidence from the Stockholm Subway, December 2009

2906 Xavier Vives, Asset Auctions, Information, and Liquidity, January 2010

2907 Edwin van der Werf, Unilateral Climate Policy, Asymmetric Backstop Adoption, and Carbon Leakage in a Two-Region Hotelling Model, January 2010

2908 Margarita Katsimi and Vassilis Sarantides, Do Elections Affect the Composition of Fiscal Policy?, January 2010

2909 Rolf Golombek, Mads Greaker and Michael Hoel, Climate Policy without Commitment, January 2010

2910 Sascha O. Becker and Ludger Woessmann, The Effect of Protestantism on Education before the Industrialization: Evidence from 1816 Prussia, January 2010

2911 Michael Berlemann, Marco Oestmann and Marcel Thum, Demographic Change and Bank Profitability. Empirical Evidence from German Savings Banks, January 2010

2912 Øystein Foros, Hans Jarle Kind and Greg Shaffer, Mergers and Partial Ownership, January 2010 
2913 Sean Holly, M. Hashem Pesaran and Takashi Yamagata, Spatial and Temporal Diffusion of House Prices in the UK, January 2010

2914 Christian Keuschnigg and Evelyn Ribi, Profit Taxation and Finance Constraints, January 2010

2915 Hendrik Vrijburg and Ruud A. de Mooij, Enhanced Cooperation in an Asymmetric Model of Tax Competition, January 2010

2916 Volker Meier and Martin Werding, Ageing and the Welfare State: Securing Sustainability, January 2010

2917 Thushyanthan Baskaran and Zohal Hessami, Globalization, Redistribution, and the Composition of Public Education Expenditures, January 2010

2918 Angel de la Fuente, Testing, not Modelling, the Impact of Cohesion Support: A Theoretical Framework and some Preliminary Results for the Spanish Regions, January 2010

2919 Bruno S. Frey and Paolo Pamini, World Heritage: Where Are We? An Empirical Analysis, January 2010

2920 Susanne Ek and Bertil Holmlund, Family Job Search, Wage Bargaining, and Optimal Unemployment Insurance, January 2010

2921 Mariagiovanna Baccara, Allan Collard-Wexler, Leonardo Felli and Leeat Yariv, Gender and Racial Biases: Evidence from Child Adoption, January 2010

2922 Kurt R. Brekke, Roberto Cellini, Luigi Siciliani and Odd Rune Straume, Competition and Quality in Regulated Markets with Sluggish Demand, January 2010

2923 Stefan Bauernschuster, Oliver Falck and Niels Große, Can Competition Spoil Reciprocity? - A Laboratory Experiment, January 2010

2924 Jerome L. Stein, A Critique of the Literature on the US Financial Debt Crisis, January 2010

2925 Erkki Koskela and Jan König, Profit Sharing, Wage Formation and Flexible Outsourcing under Labor Market Imperfection, January 2010

2926 Gabriella Legrenzi and Costas Milas, Spend-and-Tax Adjustments and the Sustainability of the Government's Intertemporal Budget Constraint, January 2010

2927 Piero Gottardi, Jean Marc Tallon and Paolo Ghirardato, Flexible Contracts, January 2010

2928 Gebhard Kirchgässner and Jürgen Wolters, The Role of Monetary Aggregates in the Policy Analysis of the Swiss National Bank, January 2010 
2929 J. Trent Alexander, Michael Davern and Betsey Stevenson, Inaccurate Age and Sex Data in the Census PUMS Files: Evidence and Implications, January 2010

2930 Stefan Krasa and Mattias K. Polborn, Competition between Specialized Candidates, January 2010

2931 Yin-Wong Cheung and Xingwang Qian, Capital Flight: China's Experience, January 2010

2932 Thomas Hemmelgarn and Gaetan Nicodeme, The 2008 Financial Crisis and Taxation Policy, January 2010

2933 Marco Faravelli, Oliver Kirchkamp and Helmut Rainer, Social Welfare versus Inequality Concerns in an Incomplete Contract Experiment, January 2010

2934 Mohamed El Hedi Arouri and Christophe Rault, Oil Prices and Stock Markets: What Drives what in the Gulf Corporation Council Countries?, January 2010

2935 Wolfgang Lechthaler, Christian Merkl and Dennis J. Snower, Monetary Persistence and the Labor Market: A New Perspective, January 2010

2936 Klaus Abberger and Wolfgang Nierhaus, Markov-Switching and the Ifo Business Climate: The Ifo Business Cycle Traffic Lights, January 2010

2937 Mark Armstrong and Steffen Huck, Behavioral Economics as Applied to Firms: A Primer, February 2010

2938 Guglielmo Maria Caporale and Alessandro Girardi, Price Formation on the EuroMTS Platform, February 2010

2939 Hans Gersbach, Democratic Provision of Divisible Public Goods, February 2010

2940 Adam Isen and Betsey Stevenson, Women's Education and Family Behavior: Trends in Marriage, Divorce and Fertility, February 2010

2941 Peter Debaere, Holger Görg and Horst Raff, Greasing the Wheels of International Commerce: How Services Facilitate Firms' International Sourcing, February 2010

2942 Emanuele Forlani, Competition in the Service Sector and the Performances of Manufacturing Firms: Does Liberalization Matter?, February 2010 